No 2010 - 17

August

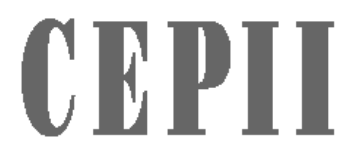

CENTE

D'RTUDE TROSFECTIVES

ET D'INFORMATIONS

INTERNATIONALE

The Credit Default Swap Market and the Settlement of Large Defaults

Virginie Coudert

Mathieu Gex 


\section{TABLE OF CONTENTS}

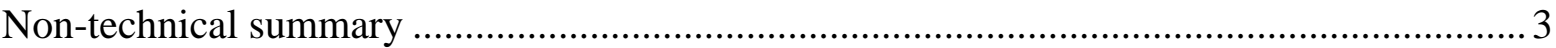

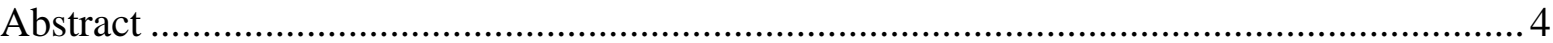

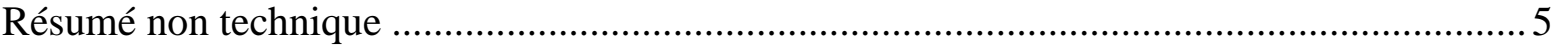

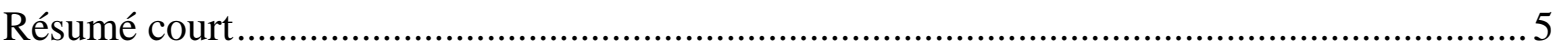

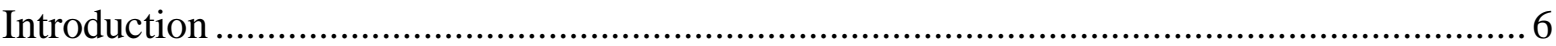

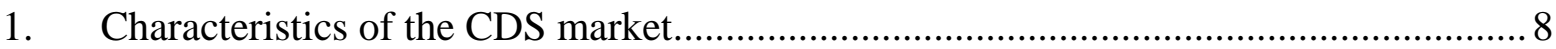

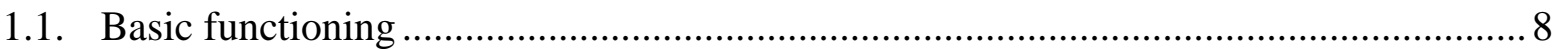

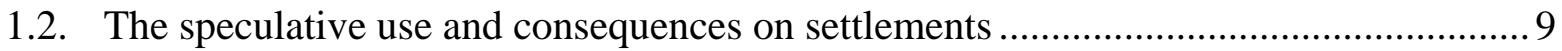

1.3. CDS and incentives for creditors of companies in financial distress ......................... 10

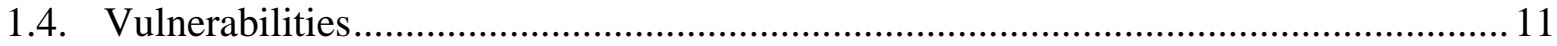

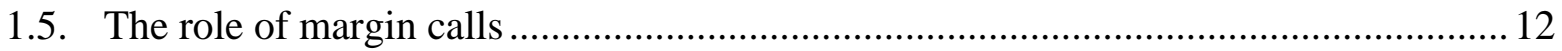

1.6. Ramifications of the AIG bail-out and the Lehman Brothers failure .......................... 12

2. Auction mechanisms in default settlement ............................................................... 13

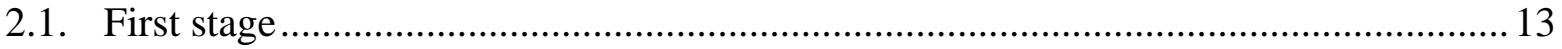

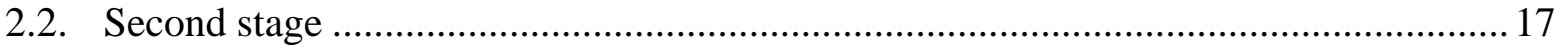

3. Links between final settlement and bond prices .................................................... 18

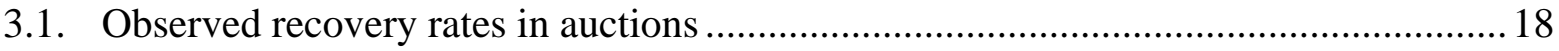

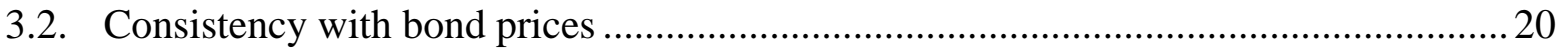

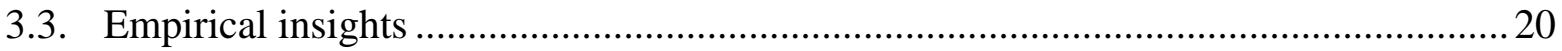

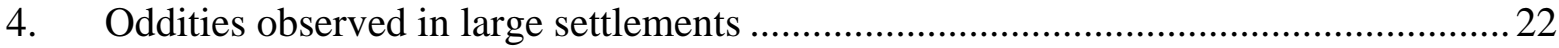

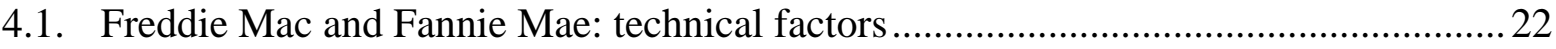

4.2. Lehman Brothers and Washington Mutual: uncertainty about the amounts at stake ...23

4.3. Thomson: squeeze effects in a restructuring credit event .......................................... 25

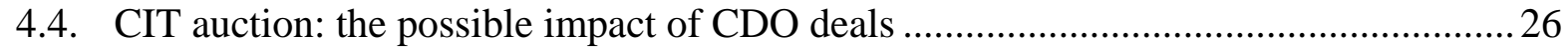

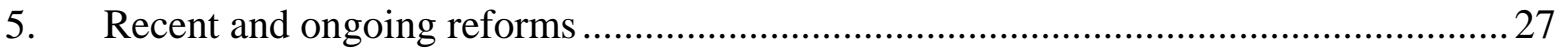

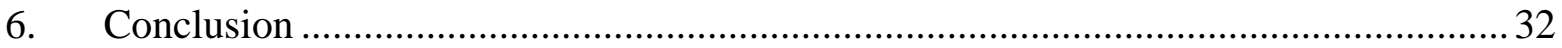

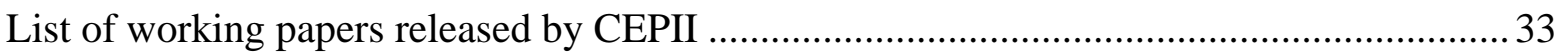




\title{
The Credit Default Swap Market AND the SETTLEMENT OF LARge Defaults
}

\author{
Virginie Coudert and Mathieu Gex
}

\section{NON-TECHNICAL SUMMARY}

The huge positions in credit default swaps (CDS) borne by market participants have raised concerns about the ability of the market to settle major entities' defaults. The near-failure and the outright failure of two major counterparties such as AIG and Lehman Brothers in 2008, have revealed the exposure of CDS's buyers to counterparty risk and hence highlighted the necessity of organizing the market, which set in motion a large train of reforms.

First we go through the functioning of the market and concentrate on its vulnerabilities. All financial derivatives have been designed for hedging risks, but in practice, they are also widely used for sheer speculation. CDS are no exception. Aimed at protecting against a borrower's default, CDS have been used much beyond this scope, for their outstanding amount now outsizes that of the bonds. Moreover, because the CDS market is highly concentrated, it has not contributed to transfer the risk properly, but has concentrated it on a handful of major institutions. We also review in the paper the main other subjects of concerns since the Lehman Brothers' failure, such as the lack of regulation of the OTC market, the interlocking positions of participants and the market opaqueness.

Second, we try to understand the resilience of the market to the major defaults occurred recently in spite of its weaknesses mentioned above. To do that, we unravel the auction process implemented to settle defaults. Because many CDS holders do not hold the underlying bond, the size of the debt to settle in case of default generally exceeds the existing amount of underlying securities. This entails a lack of deliverable bonds, which would be able to push up the price of securities artificially at the time of settlement. That is why an auction process has been designed by Markit to determine the recovery rate (or final price). The system covers physical and cash settlement at the same price. The auction has two stages, designed to determine: (i) an intermediate recovery rate, or inside market midpoint (IMM), and the sum of net buy and sell requests for physical settlement, called open interest; (ii) the recovery rate, or final price. We look into the two stages in the case of the Lehman Brothers' auction. To do that, we describe the strategies of buyers and sellers as well as the links with the bond market. We then study the way it worked for settling some other key defaults, such as Washington Mutual, CIT and Thomson, as well as for the Government Sponsored Entreprises (GSEs). As shown by these examples, the auction process has worked smoothly. However, the final price is not always exempted of biases due to the strategic behaviour of participants.

All the concerns raised during the crisis, and especially the fear of a systemic effect, have shown the need for more regulation of the market. The last section of the paper is aimed at describing the main ongoing reforms. Regulatory measures are being designed, in collaboration with the industry in order to ensure better market practices and higher risk management standards. The move to central counterpart is considered as a key tool to strengthen market resilience. The recording of transactions is also important to mitigate the market opaqueness and provide supervisors with a better view of the risks involved. 


\section{ABSTRACT}

The huge positions on the credit default swaps (CDS) have raised concerns about the ability of the market to settle major entities' defaults. The near-failure of AIG and the bankruptcy of Lehman Brothers in 2008 have revealed the exposure of CDS's buyers to counterparty risk and hence highlighted the necessity of organizing the market, which triggered a large reform process. First we analyse the vulnerabilities of the market at the bursting of this crisis. Second, to understand its resilience to major credit events, we unravel the auction process implemented to settle defaults, the strategies of buyers and sellers and the links with the bond market. We then study the way it worked for key defaults, such as Lehman Brothers, Washington Mutual, CIT and Thomson, as well as, for the Government Sponsored Enterprises. Third, we discuss the ongoing reforms aimed at strengthening the market resilience.

JEL Classification: D44; G01; G15; G33

Key Words: $\quad$ Credit derivatives, bankruptcy, credit default swap, auction. 


\title{
LE MARChÉ Des CRÉDit Défault SWAPS ET LE RÈGLEMENT DES DÉFAUTS DE GRANDE AMPLEUR
}

\author{
Virginie Coudert et Mathieu Gex
}

\section{RÉSUMÉ NON TECHNIQUE}

Les énormes positions prises par les participants sur le marché des swaps de défaut de crédit (CDS) ont soulevé des inquiétudes sur la capacité du marché à régler les défauts lorsque ceux-ci concernent de très gros emprunteurs. La quasi-faillite de AIG et la faillite avérée de Lehman Brothers en 2008 ont révélé l'exposition des acheteurs de CDS au risque de contrepartie et mis en évidence la nécessité d'organiser le marché, ce qui a déclenché un processus de réformes. Premièrement, nous analysons le fonctionnement du marché et nous concentrons sur ses vulnérabilités. Tous les marchés financiers dérivés ont été conçus pour la couverture d'un risque, mais en pratique ils sont beaucoup utilisés pour la simple spéculation. Il en est de même pour les CDS. Destinés à protéger contre le risque de défaut d'un emprunteur, les CDS sont utilisés bien au-delà de cet objet, puisque leurs montants dépassent maintenant celui des obligations. De plus, du fait de sa forte concentration, le marché des CDS n'a pas contribué à transférer les risques de manière satisfaisante mais les a concentrés sur une poignée de grandes institutions financières. Nous passons aussi en revue dans le document les principaux sujets d'inquiétude depuis la faillite de Lehman Brothers en septembre 2008, notamment le manque de régulation du marché, son opacité et les positions imbriquées des participants.

Deuxièmement, nous essayons de comprendre la résilience du marché face aux faillites majeures qui sont intervenues récemment, en dépit de toutes les faiblesses mentionnées ci-dessus. Nous analysons le processus d'enchères qui a permis de régler ces défauts. Puisque de nombreux détenteurs de CDS ne possèdent pas le titre sous-jacent, la taille de la dette à régler dépasse le montant existant de titres. Il en résulte un manque d'obligations délivrables, qui peut entrainer un renchérissement artificiel de leur prix au moment du règlement. C'est pourquoi un système d'enchère a été mis en place par Markit pour déterminer le taux de recouvrement (ou prix final du titre). Le système assure le règlement physique et monétaire au même prix. L’enchère a lieu en deux étapes destinées à déterminer : (i) le taux de recouvrement intermédiaire (ou inside market midpoint) et la somme des offres nettes d'achats et de ventes pour le règlement physique (appelée open interest) ; (ii) le taux de recouvrement ou prix final. Nous examinons ces deux étapes dans le cas de l'enchère sur Lehman Brothers. Pour cela, nous décrivons les stratégies des vendeurs et des acheteurs ainsi que les liens avec le marché obligataire. Nous étudions ensuite la façon dont ces enchères ont précisément fonctionné dans le cas de défauts majeurs, tels que Washington Mutual, CIT, et Thomson, ainsi que pour Fannie Mae et Freddie Mac. Ces exemples montrent que le système d'enchère a fonctionné de manière ordonné. Cependant, le prix final peut comporter des biais dus au comportement stratégique des participants.

Toutes les inquiétudes soulevées pendant la crise et notamment la peur d'un effet systémique ont montré qu'il fallait davantage réguler ce marché. La dernière partie du document est consacrée à décrire les réformes en cours. Des mesures réglementaires sont mises en place progressivement en collaboration avec le secteur financier afin d'améliorer les pratiques de marché et de renforcer la gestion des risques. Le passage à une contrepartie centrale est un élément clé du dispositif pour accroître la résilience du marché. L’enregistrement des transactions est aussi un élément important 
pour réduire l’opacité du marché et donner aux superviseurs une meilleure connaissance des risques qu'il comporte.

\section{RÉSUMÉ COURT}

Les énormes positions prises sur le marché des swaps de défaut de crédit (CDS) ont soulevé des inquiétudes sur la capacité du marché à régler les défauts lorsque ceux-ci concernent de très gros emprunteurs. La quasi-faillite de AIG et la faillite avérée de Lehman Brothers en 2008 ont révélé l'exposition des acheteurs de CDS au risque de contrepartie et mis en évidence la nécessité d'organiser le marché, ce qui a déclenché un processus de réformes. Premièrement, nous analysons les vulnérabilités du marché au moment de l'éclatement de la crise. Deuxièmement, pour comprendre sa résilience malgré des faillites majeures, nous analysons le processus d'enchères qui a permis de régler ces défauts, les stratégies des acheteurs et des vendeurs, ainsi que le lien avec le marché des obligations. Nous étudions ensuite la façon dont ces enchères ont précisément fonctionné dans le cas de défauts majeurs, tels que Lehman Brothers, Washington Mutual, CIT, et Thomson, ainsi que pour Fannie Mae et Freddie Mac. Troisièmement, nous analysons le processus de réformes en cours

Classification JEL : D44; G01; G15; G33

Mots-clefs : $\quad$ Dérives de crédit ; swaps de défaut de crédit ; banqueroute ; enchère 


\title{
The Credit Default Swap Market And The SetTlement of LARge Defaults
}

\author{
Virginie Coudert ${ }^{*}$, Mathieu Gex ${ }^{\dagger}$
}

\section{INTRODUCTION}

Credit derivatives, which consist chiefly of credit default swaps (CDS), have been a cause of concern since the bursting of the present financial crisis. The CDS market soared from 2004 to 2007 in step with the growth of structured finance. CDS were much used in the synthetic Collateral Debt Obligations (CDOs) as well as in the ABX indices, which are CDS indices on tranches of subprime Asset Backed Securities (ABS). The financial crisis brought the development of structured credit to a sudden halt, as CDO and ABS prices and trading volumes collapsed in 2008 (IMF, 2008). Meanwhile, the CDS stayed buoyant all through the crisis, essentially for three strands of reasons: (i) the rise in the default probability strengthens the importance of a default insurance for many investors and paves the way for speculative gains for others; (ii) new segments of the market emerged during the crisis, such as the sovereign CDS which were not really traded before at least for the advanced countries; (iii) contrary to CDOs, CDS never suffered from a lack of liquidity, as investors can offload CDS contracts by writing others in the opposite direction.

The most patent effect of the crisis on the CDS market has been the surge in the cost of protection, in line with the mounting risk of borrower default. The higher premia could also have been due to contagion effects, already evidenced on the CDS markets during previous episodes (Jorion and Zhang, 2006; Coudert and Gex, 2010a). Meanwhile the notional value of outstanding CDS fell from USD 58 trillion at the end of 2007 to USD trillion to USD 36 trillion in June 2009 (BIS, 2009). However, this decrease is not very meaningful, for it stems from the netting of positions, and not to a reduction of trade.

At the end of summer 2008, when key counterparties as AIG and Lehman Brothers were on the verge of bankrupting, confidence in the functioning of the CDS market was seriously undermined (Purtle and Yelvington, 2008; Brunnermeier, 2009). Since that time, counterparty risk has emerged as a major threat, after previously being viewed as negligible. Large financial institutions operating on the market had been thought to be reliable, whereas the near collapse of AIG and the Lehman bankruptcy gave the lie to that belief.

Fears that the failure of a major firm might bring down the entire market had been fuelled by factors such as the huge size of the CDS market, the exposure of the financial sector and the presence of interlocking, opaque positions. Mounting concerns highlighted the market's vulnerabilities and

\footnotetext{
* Banque de France, DGO, DSF, 31, rue Croix des Petits champs, 75001 Paris, France; CEPII, 9 rue George Pitard, 75015 Paris, France; EconomiX, University of Paris X. Email: virginie.coudert@banque-france.fr.

${ }^{\dagger}$ Banque de France, DGO, DSF, 31, rue Croix des Petits champs, 75001 Paris, France; CERAG, University of Grenoble, France. Email: mathieu.gex@banque-france.fr.

We thank Gunther Capelle-Blancard for helpful remarks.
} 
accelerated the introduction of reforms, including larger margin calls, netting and the establishment of a central counterparty. Nevertheless, one has to recognize that the successive defaults of major firms in 2008 and 2009 were settled orderly. For this reason it is interesting to look back on these events in order to better understand the functioning of the market and how participants' positions were settled.

The aim of this article is therefore to analyse the characteristics and vulnerabilities of the CDS market as well as the settlement process during episodes of large defaults. In particular, we unravel all the stages of the auction procedure that makes the settlement, and the strategies of the participants at each step. We rely on the descriptions made by Markit and Creditex (2010) as well as the documents provided by the International Swaps and Derivatives Association (ISDA), such as ISDA (2008). Helwege et al (2009) have also studied this auction process, considering a sample of 10 firms. Here, we broaden the sample to 27 entities in default. We also scrutinize several key episodes more closely, by analysing the defaults of Lehman Brothers, Washington Mutual, CIT and Thomson, as well as the special case of the Government Sponsored Agencies (GSEs). To do that, we use the data on the auctions released by Markit and Creditex at each stage of the process. This analysis evidences that the auction process though running smoothly have led to some oddities in recovery rates in several cases.

The remainder of the article is organised as follows. Part 2 reviews the characteristics of the CDS market and its vulnerabilities at the bursting of the present crisis. Part 3 analyses the auction procedure to settle defaults. Part 4 describes the links between the prices given by the auction process and the bond market. Part 5 analyses several major settlements that have occurred in 2008 and 2009. Part 6 describes the ongoing reforms on the CDS market.

\section{CHARACTERISTICS OF THE CDS MARKET}

\subsection{Basic functioning}

CDS are designed to cover the risk of default borne by creditors and transfer it to other agents. Three parties are involved: a protection buyer $(A)$; a protection seller $(B)$; and a reference entity $(X)$, which is the underlying borrower and may be a company or a sovereign. The CDS allows $A$ to buy protection against the risk of a default by borrower $X$, while $B$ receives payment for providing that protection.

Assume that $A$ buys a CDS on $X$ from $B$ for face value $F$. The contract covers $A$ against the risk of default by $X$ from the day of purchase $t_{0}$ to maturity $T$ (say five years).

- A agrees to pay a premium that is a percentage of the debt face value $(F \times c)$ to $B$ for the term of the agreement, (from $t_{0}$ to $T$ ), or until default, if one occurs during the period. Premiums are usually paid quarterly. Obviously, premium $c$ increases with $X$ 's probability of default and declines with the expected recovery rate, roughly following the bond spread.

- In return, $B$ agrees to pay $A$ a sum in the event of default that fully compensates $A$ 's loss.

If $X$ defaults, two settlement methods are possible:

- physical settlement, where $A$ delivers the underlying security to $B$, and $B$ pays $A$ the full face value $F$;

- $\quad$ cash settlement, where $B$ pays $A$ the amount $F \times(1-R)$, where $R$ is the recovery rate; $A$ does not deliver the underlying security.

These mechanisms are illustrated in Figure 1. In theory, under both methods, a CDS buyer who holds a bond with the same face value is fully protected by the CDS against the risk of default. This is 
obvious in the case of physical settlement. It is also true if there is a cash settlement and if the CDS market is in step with the bond market. The buyer will be able to recover $F \times R$ by reselling the bond on the secondary market and the remainder of the face value $F \times(1-R)$ to the seller.

The notion of "default" itself needs to be clarified. It generally refers to the borrower's bankruptcy or his failure to pay interest on his debt or the principal within given delays. Nevertheless, CDS settlements can be triggered by broader "credit events", including bankruptcy, such as failure to pay, but also restructuring and repudation/moratorium. These credit events are documented in great detail by the International Swaps and Derivatives Association (ISDA).

Figure 1: The functioning of a CDS

- From $t_{0}$ to default (if one occurs) or to maturity (if no default):

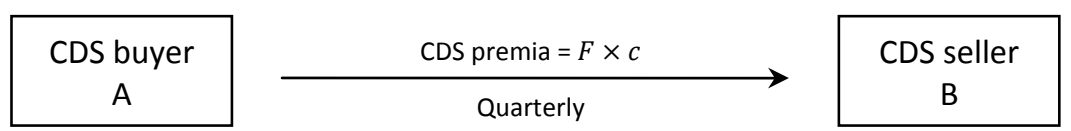

- If a default occurs, one of two things happens:

- Physical settlement:

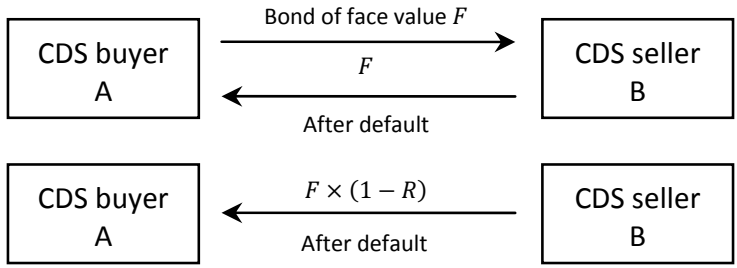

\subsection{The speculative use and consequences on settlements}

Financial derivatives, whether futures, options or swaps, are designed to hedge risky positions on the underlying assets. However, in practice, they are also widely used to speculate. CDS are no exception: though they were created to hedge default risk, many buyers use them for speculation, as they do not hold the underlying securities.

An investor may buy a CDS without holding the underlying debt, just to pocket the cash $F \times(1-R)$ in case of default. Most of the time, she buys a CDS on $X$ without even expecting a default: if she merely expects that $X$ 's probability of default assessed by the market is going to increase, she can make a profit simply by buying a CDS now and unwinding her position later.

Buying CDS without holding the underlying assets is usually referred to as "naked CDS". This speculative use of CDS comes down to short-selling bonds. It has been violently criticized, especially by European government officials during the 2010 Greek crisis. Indeed, the surging spreads on the Greek sovereign CDS have raised concerns for the cost of public borrowing in this country, which reached unbearable levels. Fearing contagion, Germany decided to ban the use of naked CDS on eurogovernment bonds in May 2010. Indeed, naked CDS market can contribute to fuel bearish speculation, just like the short-selling of bonds or stocks. On the one hand, the CDS spreads have been evidenced to lead the bond spreads in times of crises, in the corporate as well as in the sovereign segment (Coudert and Gex, 2010b), which points to their role in fuelling bearish speculation. On the other 
hand, the use of naked CDS in itself is obviously not responsible for the financial difficulties of the Greek government. According to Duffie (2010), this speculation is the result of investors' distrust, not its cause.

Indeed, the traded volumes on the CDS market exceed those of the underlying bonds for a number of companies. As an example, in the 2005 Delphi failure, the notional value of CDS (USD 28 billion) exceeded actual bonds and loans (USD 5 billion) by a factor of 5.6. Collins \& Aikman, Delta Airlines and Northwest Airlines had even higher ratios. More generally, for the non-financial corporate sector as a whole, the CDS market has nearly outsized the bond market, as it reached USD 9.5 trillion versus USD 10.0 trillion for their long-term debt securities in September 2009.

Because the amount of protection often exceeds the deliverable underlying assets, the default settlement process has changed. Settlement can no longer be exclusively physical, because this would artificially boost the price of the underlying bonds over the normally expected recovery rate. Cash settlement has therefore increased. Furthermore, some CDS on defaulting entities belonged to indices, such as the European iTraxx or the North American CDX, which are composed of a basket of CDS. A priori, investors in CDS indexes do not hold the underlying bonds. To guarantee that they will be treated fairly, a single recovery rate is necessary. Since the 2005 failures involving automotive parts manufacturers and airlines, an auction system has been introduced to provide fair treatment and to link the two settlement methods. Participation to an auction is based on a bilateral agreement, signed by the organisers of the auction (Creditex, ISDA and Markit) and any participating bidder willing to participate in the auction. This agreement also specifies which jurisdiction applies in case of dispute, generally New York State law for American reference entities, English law for other contracts.

\subsection{CDS and incentives for creditors of companies in financial distress}

Before the CDS market emerged, creditors were often tempted to let a financially distressed company survive for a while - even if this meant giving up part of their claims - so that it could get past the critical deadlines. In some cases the extra time was enough to save the company from failure. By acting in this way, creditors were doing their best to avoid bankruptcy proceedings, which would involve either a drawn-out and uncertain recovery process or a fire-sale of the debt on a secondary market.

CDS may have reversed the usual incentives for creditors, although few papers have been devoted to this topic, outside Matthews and Yelvington (2008). If the value of creditors' debt is fully covered by a CDS, then it is in their interest for the company to fail as quickly as possible, because failure automatically activates CDS settlement within less than a month and creditors can be sure of recouping the entire face value of their claim. The prospect of swift, full payment removes any incentive to negotiate or grant new loans or extra time. CDS holders who do not possess the underlying claim are especially impatient for default to occur. Moreover legal issues may complicate matters and hinder creditors from negotiating before a failure if they have CDS protection. Taking part in talks may provide them with inside information, which the US Securities and Exchange Commission views as incompatible with holding CDS positions.

As regards contracts in which failed entities are counterparties (such as in the Lehman case), the US bankruptcy code was amended in October 2005 to clarify the safe harbour status of financial

\footnotetext{
${ }^{1}$ CDS figures concern gross notional amounts of single-name CDS for non-financial corporates, source: DTCC, those for long-term securities are extracted from the BIS.
} 
instruments, including forwards, swaps and CDS (Matthews and Yelvington, 2008). The amendments also facilitated netting of contracts between different counterparties and the failed entity.

\subsection{Vulnerabilities}

Although the situation is changing, at the time the subprime crisis burst out, the CDS market was exclusively an over-the-counter (OTC) market with no central counterparty, which created a number of vulnerabilities (Segoviano and Singh, 2008; Singh and Aitken, 2009). The failure of a major firm caused counterparty risk to materialise truly for the first time on the CDS market, with AIG's bailout and Lehman's bankruptcy. Several factors contributed to magnify concerns, including interlocking positions, the financial sector's exposure concentrated on a handful of major institutions, market opaqueness.

Interlocking positions resulted from the nature of the OTC market, which played a part in increasing the number of contracts. An agent wishing to withdraw from a contract cannot usually sell it or tear it up. Instead he has to write a new contract in the opposite direction with another counterparty to offset the original (Longstaff et al., 2005). This singular method of functioning engenders a larger number of participants, interlocking positions between financial participants and increased counterparty risk. Incidentally it is also the reason for the huge amounts outstanding in the underlying contracts: outstanding notional amounts reached USD 58 trillion in gross terms at the end of 2007, before coming down to USD 36 trillion in June 2009 because of the netting of positions, according to BIS (2009) statistics. Taking the market value of contracts rather than the notional value, the market is estimated at USD 2 trillion at end-2007 and USD 3 trillion in June 2009 (BIS, 2009).

The financial sector has considerable exposure. The credit derivatives market has not transferred risk as it was supposed to. The market, buyers and sellers alike, is dominated by financial participants. Risk that was supposed to be taken out of the financial sector has remained concentrated there. Banks accounted for $58 \%$ of CDS buyers and $43 \%$ of sellers in 2006, while hedge funds accounted for $29 \%$ of buyers and 31\% of sellers (IMF, 2008).

The crisis led to a higher concentration of the market. First, some major CDS dealers, such as Bear Stearns, Lehman Brothers and Merrill Lynch, exited the market. These entities were among the top 12 counterparties on the CDS market by trade count and notional amount before the crisis (Fitch, 2007). Second, smaller players, such as non-bank institutions, retreated from the market after experiencing losses in the aftermath of Lehman Brothers' bankruptcy, according a study by the ECB (2009) using the BIS statistics. Third, deleveraging strategies have dampened the appetite for protection selling, which resulted in a reduction in the activity of some major protection sellers, such as hedge funds, monolines or credit derivatives product companies (CPDC). The collapse of synthetic CDOs and SIVs also played a role in this reduction. Consequently, the ten main dealers accounted for over $90 \%$ of CDS gross notional values at the world level, at the end of 2008. More strikingly, the five main commercial banks were responsible for $97 \%$ of gross notional values in the United States ${ }^{2}$.

Moreover, the most traded CDS concern reference entities in the financial sector. Protection sold on financial reference entities amounted to $40 \%$ of the gross outstanding of single-name CDS (Duquerroy et al., 2009). This evolution has reinforced the risk of double default, as illustrated by the failure of Lehman Brothers, which was at the same time a major CDS dealer and a highly traded reference entity. This increasing concentration of the CDS market have resulted in a greater systemic risk, due to

\footnotetext{
2 Source: Office of the Comptroller of the Currency (OCC). Total gross notional amounts (bought and sold) for J.P. Morgan amounted to USD 8,391 billion at end-2008, or 30\% of worldwide activity.
} 
the transfer of credit risk between a smaller number of market participants, that are simultaneously protection buyers and sellers, as well as underlying entities. This has contributed to the emergence of the "too interconnected to fail" risk, which has overridden the "too big to fail" risk (Brunnermeier, 2009).

Market opaqueness was another source of concern, because it created great uncertainty about the exposure of different participants. The OTC nature of the CDS market makes it difficult to estimate the size of the market. At the time of Lehman Brothers' bankruptcy, only aggregated data were available to the public through two main data providers, BIS and ISDA. Moreover, the lack of harmonisation of the respective data collection processes, in terms of type of products and number of reporting institutions, for instance, and the use of different definitions, hampered a precise assessment the exposure of market participants. Given the amounts in play, doubts were expressed about the ability of sellers of protection on Lehman Brothers to honour their commitments. In particular there were concerns that some hedge funds might fail, worsening the systemic risk.

\subsection{The role of margin calls}

To mitigate risk of non-payments, an initial margin is generally posted when the contract is signed; then, regular (typically daily) margin calls, ensure that provisions are set aside for future settlement. For OTC markets, these margin calls are made on a bilateral basis. When a borrower begins to run into problems, several mechanisms are activated to trigger additional margin calls. The signal may be an increase in the CDS premium or a decline in the price of the bond; in some cases, especially in the United States, it may be a rating downgrade for the reference entity or seller.

Generally speaking, margin calls are aimed at guarantying that the CDS seller will be able to meet the final payment if needed. The rising margin calls are deducted from the payments made in the event of a default. This collateralisation procedure is usually included in contracts between dealers. In the case of transactions between dealers and non-dealers, 66\% of CDS issued in 2008 were collateralised, mainly through cash payments, according to ISDA $^{3}$. One limitation of the margin call process concerns the "jump-to-default", or the sudden increase in CDS premiums before a default, which often leaves little time to adjust margin calls.

In the case of Lehman Brothers, bonds were still trading at over $80 \%$ of their par value less than two weeks before the failure, implying margin calls of approximately $20 \%$ of the CDS notional. In the days after the default, bonds fell to $30 \%$ of par, triggering margin calls of $70 \%$. When the settlement auction was held, bonds had fallen again to $13 \%$ of par, so margins were $87 \%$. Since the final settlement price was $8.625 \%$ of par, just $4 \%$ of the notional remained for sellers to deliver (Gerson Lehrman Group, 2008).

\subsection{Ramifications of the AIG bail-out and the Lehman Brothers failure}

AIG, the US largest insurance company, was a major player in the CDS market before its near failure in September 2008. In particular, it had sold huge amounts of CDS on CDOs including US subprime mortgage. The subprime crisis forced AIG to mark down theses assets. When AIG was downgraded by rating agencies in September 2008, AIG's counterparties asked for more collateral, to such an extent that AIG was not able to meet the collateral-calls on its CDS (Weistroffer, 2009). As AIG was not able to raise more liquidity on the market, it was on the verge of failing. Because of the giant size of the company and its interconnections with all major financial institutions in the world, its failure

\footnotetext{
${ }^{3}$ Source: ISDA Margin Survey 2009.
} 
would have had a disastrous systemic effect on the global financial system. In other words, AIG was typically "too big to fail". That is the reason why it was bailed out by the Fed.

Lehman Brothers was the fourth-largest US investment bank. As a key participant in the subprime securitisation process, it had kept heavy exposure to the riskiest tranches on its balance sheet. As Lehman Brothers sustained major losses after the subprime crisis erupted in summer 2007, its share price dropping by $73 \%$ in the first half of 2008 , it was forced to sell off assets. Lehman announced its bankruptcy on 15 September $^{5}$ and filed for Chapter 11 protection $^{6}$. On 10 October, three weeks after the failure, CDS were settled through an auction. We review below this settlement process, taking Lehman as an example.

\section{Auction Mechanisms in Default SetTlement}

The auction process is designed by Markit to determine a recovery rate, or final price. The system covers physical settlement. A Dutch auction is used to exchange securities and determine the final price. Cash settlement then takes place at the same price. The system makes it possible to exchange bonds without pushing up the price of the debt.

The auction has two stages, which are used to determine, in succession: (i) an intermediate recovery rate, or inside market midpoint (IMM), and the sum of net buy and sell requests for physical settlement, called open interest; (ii) the recovery rate, or final price.

\subsection{First stage}

Only a small number of dealers participate in this stage (14 in the case of the Lehman auction). These represent all the possible counterparties (or market makers) for investors wanting to buy or sell protection on the defaulting entity. These dealers handled all the CDS written on this name ${ }^{7}$.

The first stage of the auction includes two types of data provided by dealers:

- A bid/offer spread (as a percentage of the par) at which they are ready to buy or sell bonds (see matched markets, Table 1). The size of the spread was generally $2 \%$ in the Lehman auction. For example, according to the first line in Table 1, Bank of America was ready to buy Lehman Brothers' bond at $9.5 \%$ of the par and to sell it at $11.5 \%$. The associated amount is USD 5 million or the lowest face value of deliverable debt securities (USD 5 million in the case of Lehman Brothers), whichever is higher

- A net amount corresponding to the volume of bonds that the dealer wants to buy or sell in a physical settlement.

Dealers have a 15-minute window to transfer the data to the Creditex electronic platform.

\footnotetext{
4 In summer 2008, its market capitalisation totally collapsed as the share price fell from a high of USD 85.8 in February 2007 to USD 3.7 on 12 September 2008.

${ }^{5}$ As previous negotiations with potential buyers failed (Korea Development Bank, Barclays and Bank of America).

${ }^{6}$ On 20 September the courts ruled that Barclays could take over Lehman's North American operations and New York building. On 22 September Nomura announced that it was taking over the Asia Pacific operations, followed by the investment banking business in Europe and the Middle East.

${ }^{7}$ To have CDS dealer status, an entity has to be on the list of CDS dealers, which is held by ISDA and posted on the association's website.
} 
Table 1: Bid/offer spread (matched markets) for the Lehman Brothers auction

\begin{tabular}{|c|c|c|c|}
\hline Dealer & Bid & Offer & Dealer \\
\hline Banc of America Securities LLC & 9.5 & 11.5 & Banc of America Securities LLC \\
\hline Barclays Bank PLC & 8 & 10 & Barclays Bank PLC \\
\hline BNP Paribas & 9 & 11 & BNP Paribas \\
\hline Citigroup Global Markets Inc. & 9.25 & 11 & Citigroup Global Markets Inc. \\
\hline $\begin{array}{r}\text { Credit Suisse Securities (United } \\
\text { States) LLC }\end{array}$ & 8 & 10 & $\begin{array}{l}\text { Credit Suisse Securities (United } \\
\text { States) LLC }\end{array}$ \\
\hline Deutsche Bank AG & 8 & 10 & Deutsche Bank AG \\
\hline Dresdner Bank AG & 9.5 & 11.5 & Dresdner Bank AG \\
\hline Goldman Sachs \& Co & 8.875 & 10.875 & Goldman Sachs \& Co \\
\hline $\begin{array}{r}\text { HSBC Bank United States, } \\
\text { National Association }\end{array}$ & 10 & 12 & $\begin{array}{l}\text { HSBC Bank United States, National } \\
\text { Association }\end{array}$ \\
\hline $\begin{array}{r}\text { JPMorgan Chase Bank, National } \\
\text { Association }\end{array}$ & 9 & 11 & $\begin{array}{l}\text { JPMorgan Chase Bank, National } \\
\text { Association }\end{array}$ \\
\hline $\begin{array}{r}\text { Merrill Lynch, Pierce, Fenner \& } \\
\text { Smith Inc. }\end{array}$ & 8 & 10 & $\begin{array}{l}\text { Merrill Lynch, Pierce, Fenner \& Smith } \\
\text { Inc. }\end{array}$ \\
\hline Morgan Stanley \& Co. Inc. & 8.25 & 10.25 & Morgan Stanley \& Co. Inc. \\
\hline The Royal Bank of Scotland PLC & 9.25 & 11.25 & The Royal Bank of Scotland PLC \\
\hline UBS Securities LLC & 8.75 & 10.75 & UBS Securities LLC \\
\hline
\end{tabular}

\section{IMM}

Bids and offers are sorted so that the highest bids are matched with the lowest offers (Table 2). In other words, bids are sorted in descending order, offers in ascending order.

To obtain the IMM, matched orders, i.e. for which there is a bid equal to or higher than an offer (called "tradeable markets"), are eliminated. In the Lehman Brothers case, the HSBC bid was matched with the Barclays offer. These two prices were taken out (first shaded line in Table 2), leaving $13 \mathrm{bid} / \mathrm{offer}$ pairs. 
Table 2: IMM for Lehman Brothers auction ${ }^{\mathrm{a}}$

\begin{tabular}{|c|c|c|c|}
\hline Dealer & Bid & Offer & Dealer \\
\hline $\begin{array}{r}\text { HSBC Bank United States, National } \\
\text { Association }\end{array}$ & 10 & 10 & Barclays Bank PLC \\
\hline Banc of America Securities LLC & 9.5 & 10 & $\begin{array}{l}\text { Credit Suisse Securities (United States) } \\
\text { LLC }\end{array}$ \\
\hline Dresdner Bank AG & 9.5 & 10 & Deutsche Bank AG \\
\hline Citigroup Global Markets Inc. & 9.25 & 10 & $\begin{array}{l}\text { Merrill Lynch, Pierce, Fenner \& Smith } \\
\text { Inc. }\end{array}$ \\
\hline The Royal Bank of Scotland PLC & 9.25 & 10.25 & Morgan Stanley \& Co. Inc. \\
\hline BNP Paribas & 9 & 10.75 & UBS Securities LLC \\
\hline $\begin{array}{r}\text { JPMorgan Chase Bank, National } \\
\text { Association }\end{array}$ & 9 & 10.875 & Goldman Sachs \& Co \\
\hline Goldman Sachs \& Co & 8.875 & 11 & BNP Paribas \\
\hline UBS Securities LLC & 8.75 & 11 & Citigroup Global Markets Inc. \\
\hline Morgan Stanley \& Co. Inc. & 8.25 & 11 & $\begin{array}{l}\text { JPMorgan Chase Bank, National } \\
\text { Association }\end{array}$ \\
\hline Barclays Bank PLC & 8 & 11.25 & The Royal Bank of Scotland PLC \\
\hline $\begin{array}{r}\text { Credit Suisse Securities (United States) } \\
\text { LLC }\end{array}$ & 8 & 11.5 & Banc of America Securities LLC \\
\hline Deutsche Bank AG & 8 & 11.5 & Dresdner Bank AG \\
\hline $\begin{array}{r}\text { Merrill Lynch, Pierce, Fenner \& Smith } \\
\text { Inc. }\end{array}$ & 8 & 12 & $\begin{array}{l}\text { HSBC Bank United States, National } \\
\text { Association }\end{array}$ \\
\hline
\end{tabular}

The IMM is the mean (rounded to the nearest one-eighth) of the best half (i.e. highest) of bids and the best half (i.e. lowest) of offers. Half of 13 is rounded to the next whole number, making seven pairings (framed area of Table 2). The IMM is thus 9.75\% (9.80\% to the nearest one-eighth).

\section{Open interest}

Each dealer also indicates: (i) the amount of bonds (and thus CDS) that it wants to trade in a physical settlement; and (ii) a direction (bid or offer) The open interest is the difference between the amount of bonds bid and offered that the 14 dealers want to physically settle at the IMM price. It may be buy open interest or sell open interest, because of the possibility of cash settlement. Physical settlement is used to liquidate bond positions.

In the Lehman auction, the amount of bonds that dealers wanted to sell exceeded the amount they wanted to buy (Table 3). Net open interest was therefore to sell. In physical settlement, if there is no auction, protection buyers have to deliver the discounted bond; in the case of an auction, they have to 
sell it. This interest to sell can be understood to reflect an excess supply of bonds that will put downward pressure on prices in the second stage.

Table 3: Physical settlement requests in the Lehman Brothers auction

\begin{tabular}{lcc}
\hline \multicolumn{1}{c}{ Dealer } & $\begin{array}{c}\text { Amount } \\
\text { (USDm) }\end{array}$ & Bid/Offer \\
\hline BNP Paribas & 141 & Offer \\
Banc of America Securities LLC & 170 & Offer \\
Citigroup Global Markets Inc. & 187 & Offer \\
Credit Suisse Securities (United States) LLC & 191 & Offer \\
Deutsche Bank AG & 390 & Offer \\
Goldman Sachs \& Co & 464 & Offer \\
HSBC Bank United States, National Association & 480 & Offer \\
Merrill Lynch, Pierce, Fenner \& Smith Inc. & 574 & Offer \\
Morgan Stanley \& Co. Inc. & 755 & Offer \\
The Royal Bank of Scotland PLC & 870 & Offer \\
UBS Securities LLC & 1,470 & Offer \\
Barclays Bank PLC & 30 & Bid \\
Dresdner Bank AG & 130 & Bid \\
JPMorgan Chase Bank, National Association & 612 & Bid \\
\hline Sum of Buy Physical Requests & 772 & \\
Sum of Sell Physical Requests & 5,692 & \\
Sum of Physical Request Trades & 772 & \\
Sum of Limit Order Trades & 4,920 & \\
\hline
\end{tabular}

Net Open Interest: USD 4.92 bn to sell

Source: Creditex, Markit.

\section{Adjustment amount}

A penalty system is in place to ensure that dealers do not deliberately quote off-market prices to skew the outcome. If a dealer is on the "wrong side" of the $\mathrm{IMM}^{8}$, it has to pay the amount of the quote multiplied by the difference between the IMM and its price. The penalty is paid only if the bid (offer) crosses with an offer (bid) when the IMM is calculated. For example, HSBC's bid (10\%) was higher than the IMM (9.75\%), as shown in Table 2. Since the net open interest was to sell, the bid was on the wrong side and crossed with the Barclays offer (also 10\%). HSBC was therefore subject to a penalty

\footnotetext{
${ }^{8}$ i.e. a bid that exceeds the IMM when the open interest is to sell, which would drive the price upwards when it is supposed to go down; or an offer that is below the IMM when the open interest is to buy, which would pull the price downwards when it is supposed to go up.
} 
of USD 5 million $x(10 \%-9.75 \%)=$ USD $12,500^{9}$. This penalty compensated exactly for the fact that in the second stage HSBC bought at a lower price (IMM of 9.75\%) than the one it offered (10\%).

\subsection{Second stage}

All information on the first stage is released publicly on the Creditex website. After the publication of the results, dealers and investors can determine their limit orders for the second part of the auction during a 2-3 hour window. In the second stage, participation is no longer restricted to dealers: all final protection holders who wish to physically settle may take part. They send limit orders to their dealers $^{10}$. These orders are forwarded to the auction administrator and used to exhaust the open interest calculated in the last stage. Since the direction of the open interest (buy or sell) is known at the end of the first stage, limit orders are only in the relevant direction, i.e. sell in the case of Lehman Brothers.

The orders submitted by the main dealers in the first part of the auction are entered in the order book. Orders that cross in the first stage (HSBC and Barclays in this case) go through at the IMM, typically in an amount of USD 5 million. Next, for open interest to sell, orders are used in the following manner. The highest buy order is matched at the amount requested, then the next highest order is filled and so on until the open interest or the order book is exhausted. If the open interest is used up first, the final price is that of the last limit order to be executed. If the order book runs out, the final price is the par when open interest is to buy and zero in the case of sell open interest.

In the Lehman auction, the first 71 orders used up all the sell open interest. The final orders to be placed are framed in Table 4. The final price thus came out at $8.625 \%$, which is very low. The last four orders were not completely filled but were executed pro rata to exhaust the open interest.

An additional procedure prevents price manipulation by ensuring that the final price does not deviate too much from the IMM. If the last limit order results in a price that deviates by more than a specified cap amount (typically $1 \%$ of par) ${ }^{11}$, the final price will be set at the IMM plus or minus the cap amount. This procedure is applied only when the difference between the final price and the IMM is on the wrong side, i.e. positive in the case of sell open interest and negative in the case of buy open interest. The procedure was not activated in the Lehman auction. The difference between the price of the last order (8.625\%) and the IMM (9.75\%) was $-1.125 \%$, i.e. on the right side for sell open interest, because it makes sense for the price to fall when there is an excess of sell orders. The final price was therefore $8.625 \%$ after the second stage of the auction.

\footnotetext{
${ }^{9}$ Adjustment amounts are paid as a penalty to the ISDA, which uses them to defray the costs of holding the auction. If the amount of penalties exceeds the cost of the auction, the remaining amount is distributed pro rata to dealers that are net buyers of bonds.

${ }^{10}$ A limit order indicates a bid or offer price and will be executed only if there is an equivalent or better counterparty. It may be partially filled if there are not enough of the corresponding securities in the order book.

${ }^{11}$ The protocol for the Lehman Brothers auction set a cap amount of $1 \%$.
} 
Table 4: Establishing the final price in the Lehman Brothers auction

\begin{tabular}{lcc}
\hline \multicolumn{1}{c}{ Dealer } & Bid & Size \\
\hline Goldman Sachs \& Co & 10.75 & 50 \\
$\ldots$ & $\ldots$ & $\ldots$ \\
Banc of America Securities LLC & 8.75 & 10 \\
\hline JPMorgan Chase Bank, National Association & 8.625 & 500 \\
Banc of America Securities LLC & 8.625 & 10 \\
UBS Securities LLC & 8.625 & 5 \\
Goldman Sachs \& Co & 8.625 & 5 \\
\hline Barclays Bank PLC & 8.5 & 50 \\
$\ldots$ & $\ldots$ & $\ldots$ \\
Goldman Sachs \& Co & 0.125 & 4000 \\
\hline
\end{tabular}

Source: Creditex, Markit.

\section{Links Between FinAl SETtlement ANd Bond PRICES}

\subsection{Observed recovery rates in auctions}

In the case of Lehman Brothers, the recovery rate was extremely low, only $8.675 \%$ of facial value. Historical data for previous auctions can be used to observe the recovery rates obtained in other defaults on the CDS market (Figure 2). On average, over the 2005-2009 period, the CDS recovery rate was $31 \%$. However, this figure is definitely overstated because it includes the settlement for CDS on government-sponsored enterprises (GSEs), i.e. Fannie Mae and Freddie Mac, where the recovery rate was over $90 \%$. In this case, the holders of CDS on these entities triggered the default clauses, even though the debt was guaranteed by the US government. Fannie Mae and Freddie Mac can therefore be viewed as unrepresentative "false" defaults and should be removed from the sample.

When GSEs are taken out of the sample, the average recovery rate is $26 \%$ for the $2005-2009$ period. It falls to $13 \%$ between the Lehman Brothers failure and the end of July 2009 from 36\% before. There is therefore a downward trend typical of recessions or financial crises. At the end of 2009, recovery rates however posted a sharp increase (62\% on average on the five last months of 2009), partly due to the improvement of the global economic environment and the specificities of several defaults. These figures show how wrong it is to assume constant recovery rates when extracting probabilities of default from CDS premiums, although it is commonly done by market participants. This point is well made by Duffie (1999). More recently, Andritsky and Singh (2006) and Singh and Spackman (2009) have also evidenced that CDS premiums are highly affected by changes in recovery rates during periods of financial distress. 
Figure 2: Recovery rates (CDS auctions’ final prices) from 2005 to 2009

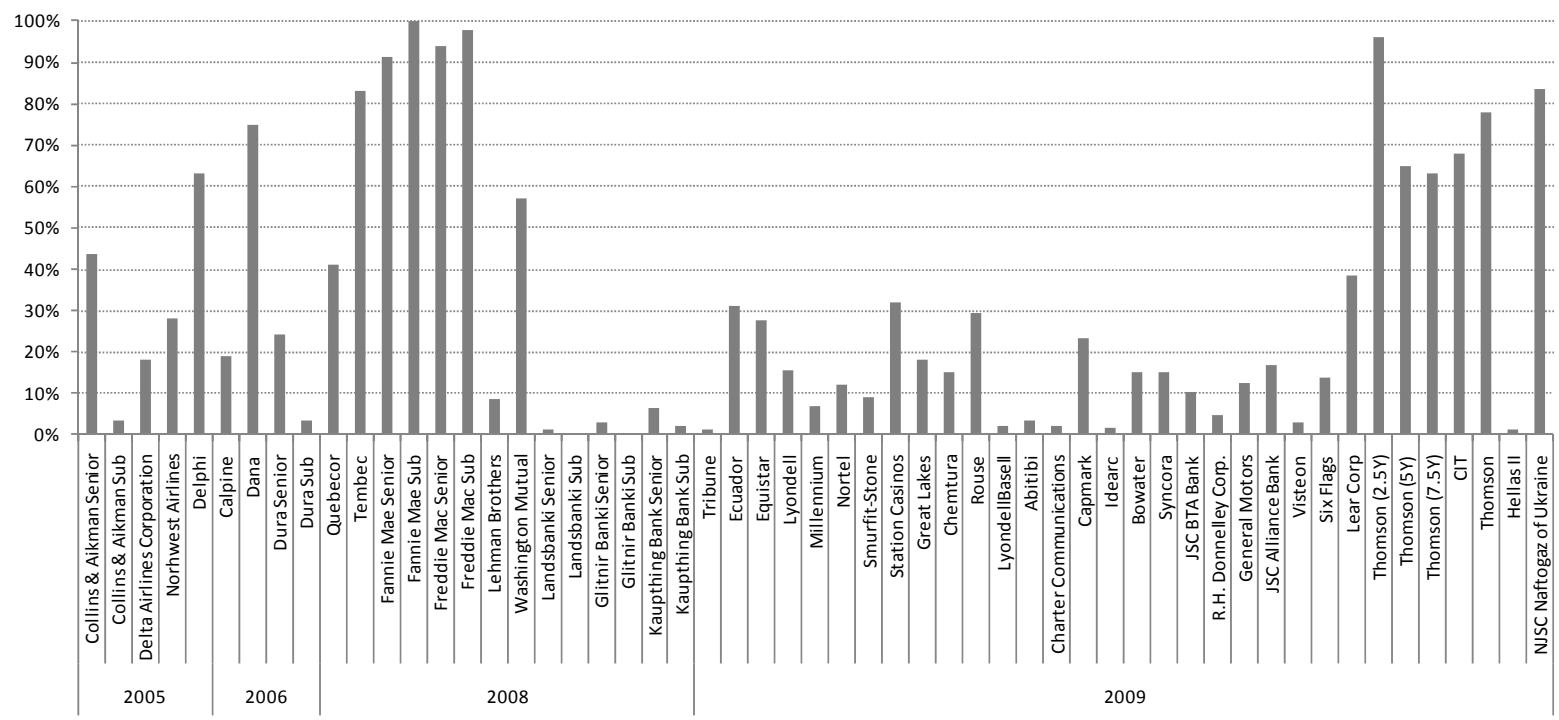

Note: LCDS auctions have been excluded. Sources: Creditex, Markit.

\subsection{Consistency with bond prices}

Roughly speaking, as a CDS hedges the risk of default of a bond, holding a portfolio containing a bond and a CDS is equivalent to a long position in a risk-free asset. Therefore, the yield rate of the bond minus the CDS premium should approximately be equal to the risk-free rate (Duffie, 1999; Hull and White, 2000).

$$
y_{t}-c_{t} \simeq r_{t}
$$

where $y_{t}$ denotes the bond yield, $c_{t}$ the CDS premium on the same entity at the same maturity , and $r_{t}$ the risk-free rate at the same maturity.

This relationship is only approximate, for a number of reasons that have to do with differences in the nature of bond and CDS markets. The main differences are due to accrued interest, the "cheapest to deliver option”, the liquidity premium, counterparty risk, etc. (O’Kane and McAddie, 2001; AunonNerin et al., 2002; Cossin and Lu, 2004; Olléon-Assouan, 2004; De Wit, 2006). Arbitrage between the two markets generally ensures some convergence towards this relation in the long-run, as shown by some empirical studies using vector error correction models on different samples (Baba and Inada, 2007; Norden and Weber, 2004; Blanco et al., 2005; Crouch and Marsh, 2005; Zhu, 2006). The adjustment process may depend on several factors, the CDS market having a tendency to lead the bond market in bearish periods (Coudert and Gex, 2010b)

The portfolio long in bonds and in the matching CDS is equivalent to a risk-free asset, not only in returns but also in price level. To illustrate the point, let us make the simplifying assumptions of a constant risk-free rate equal to the discount rate. In this case, a portfolio composed by a bond of facial value EUR 1 and the corresponding CDS is equivalent to a risk-free rate bond of facial value EUR 1:

$$
P_{t}+C_{t} \simeq 1
$$


where $P_{t}$ is the price of the bond and $C_{t}$ the price of the CDS a time $t$.

This relationship should hold at the time of the settlement, denoted $t_{1}$. At that time, the CDS price is worth $\left(1-R_{S}\right)$, where $R_{S}$ is the final recovery price. The price of the bond should move accordingly to meet the final price of the auction.

$$
P_{t_{S}} \simeq R_{S}
$$

In other words, the recovery rate found by the auction is expected to be close to the price of the bond market at the same time.

In reality, this relationship between the bond price and the final price of the auction only holds approximately, and may unravel as arbitrage opportunities become scarcer (Martin and Lasarte, 2008). This is because the CDS market is frozen just before the settlement procedure, whereas the secondary market can continue to accept trades, as some investors are specialised in the distressed segment. The auction system seeks to limit the differences between the two markets and mostly manages to do so (Helwege et al., 2009). As a matter of fact, the auction process allows CDS buyers and sellers who would prefer a cash settlement to confront demand and supply of deliverable bonds on a temporary market. The final price should naturally be close to the prices on the secondary bond market, ensuring for a CDS buyer, equivalence between the settlement of her CDS contracts within the auction or by buying underlying bonds on the secondary market and delivering them to the CDS seller.

\subsection{Empirical insights}

One way to assess the consistency of the recovery rate determined by the auction process and the prices on the secondary market is to compare the evolution of the deliverable obligation daily prices and the final price. To do so, we start from the sample of entities reported in Figure 2, that defaulted over the period 2005-2009, and select those for which bonds prices are available in Bloomberg. We exclude securities with too low liquidity, as measured by the number of missing values over the period spanning from the day of the credit event to the settlement date ${ }^{12}$. After filtering, we get a sample made of 27 senior CDS auctions ${ }^{13}$.

Figure 3 compares the final price to the average price of deliverable bonds, for each of the 27 auctions. The graph on the left gives the bond price the day of the credit event. The graph on the right is taken the day of the auction. As expected, all the observations are distributed closely around the bisecting line. However, observations are much closer to this line the day of the auction, in the right hand-side graph, as the relationship is much stronger. By comparing these two graphs, we clearly observe a tightening of the gap between the bond prices and the final price, from the day the credit event is announced until the day of the auction. This confirms the reduction in arbitrage opportunities before the auction date. Various factors yield the remaining divergences, justifying that arbitrage opportunities could hardly be cancelled. These factors are related to those mentioned in section 4.2. The auctions described in the next section reports some cases of distortions.

\footnotetext{
${ }^{12}$ Timelines of the auctions come from ISDA protocols and press releases relates to these auctions.

${ }^{13}$ Collins \& Aikman, Delta Airlines, Northwest Airlines, Delphi, Calpine, Dana, Dura, Quebecor, Freddie Mac, Fannie Mae, Lehman Brothers, Washington Mutual, Ecuador, Lyondell, Nortel, Smurfit-Stone, Rouse, Great Lakes, Capmark, JSC BTA Bank, JSC Alliance Bank, General Motors, Six Flags, Lear Corp, Bradford \& Bingley, CIT, Naftogaz.
} 
Figure 3: Final price of the auction compared to deliverable bond price taken the day of the credit event announcement and the day of the auction, for $\mathbf{2 7}$ entities.

Price of bond the day of the credit event

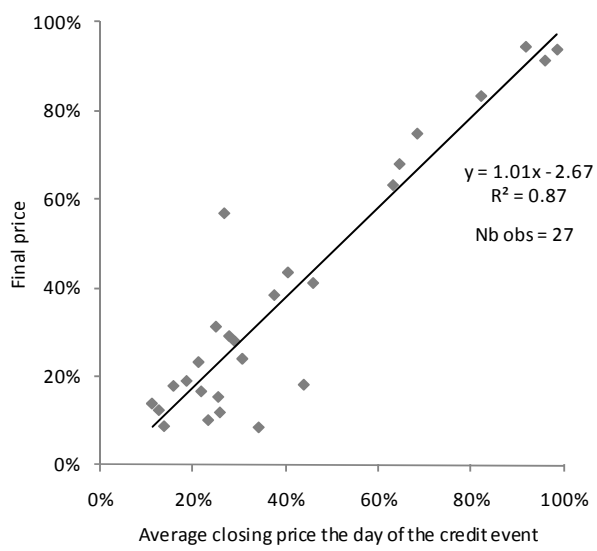

Price of bond the day of the auction

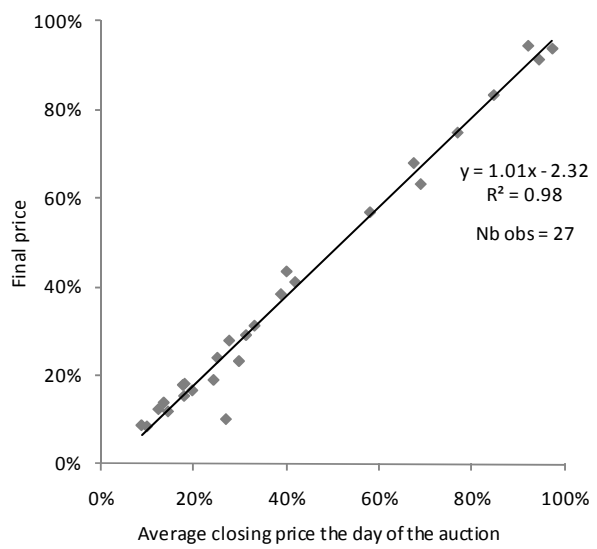

Sources: Bloomberg, Creditex, ISDA, Markit.

Another issue is to consider the evolution in the bond price in the immediate aftermath of the auction. This is interesting since the settlement does not take place immediately after the auction, but only after several days. Therefore, profits can be made ex post if a discrepancy has appeared between the final rate of the auction and the bond price on the secondary market. An examination of the data for our sample of 27 entities shows that this is the case. On the whole, there is a large gap between the two prices, as shown in Figure 4. In most cases, the price bond is higher than the final price, which means that the bond on the defaulted entity has bounced back, and performed much better than expected.

Figure 4: Gap between bond price at settlement date and final price, in percentage.

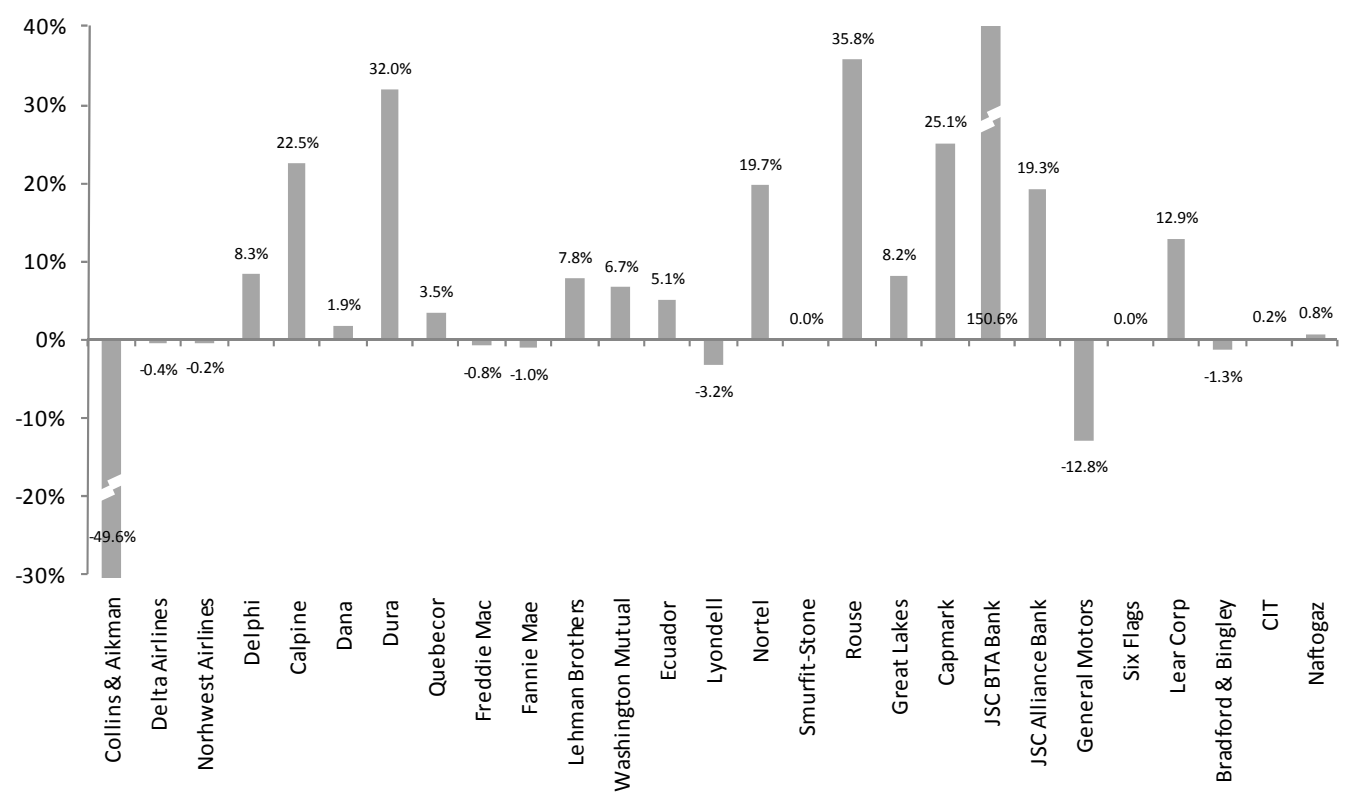

Sources: Bloomberg, Creditex, ISDA, Markit. 


\section{ODDITIES OBSERVED IN LARGE SETTLEMENTS}

Until now, default settlements on the CDS market have been implemented in an orderly manner. However, a closer look at various settlements evidences some oddities in the final recovery rates, as shown below. The stakes are different from one firm to the other, according to the kind of event that has triggered the settlement. The credit event can be a U.S. government's seizure in the case of Fannie Mae and Freddie Mac, a bankruptcy as for Lehman Brothers, Washington Mutual and CIT, or a debt restructuring for Thomson.

\subsection{Freddie Mac and Fannie Mae: technical factors}

Technical factors can influence the final price. Auctions on the CDS linked to Freddie Mac and Fannie Mae have raised questions on the efficiency of the auction process and the quality of CDS as hedging tools. On September 8 2008, both GSEs were taken into conservatorship by the US Treasury, which constituted a credit event and triggered CDSs on the senior and subordinated debt of the two firms. This event was considered as a technical default, according to the ISDA documentation.

In a physical settlement, CDS sellers will prefer to deliver the cheapest underlying bonds, which are often bonds with optional features, to CDS buyers. The presence of deliverable bonds with specific characteristics could then push the final price down. As a large amount of the GSEs' senior debt included such features and was quoted at a lower price than straight bonds, the ISDA drew up a list of deliverable obligations which excluded the majority of these kinds of bonds, mainly zero-coupon notes. However, the decision to include callable obligations and range accruals in the list still contributed to lower expectations of recovery rates (Pengelly, 2008). The auction ended with final prices of $91.51 \%$ for Fannie Mae and $94 \%$ for Freddie Mac, far from prices on the secondary market, $98 \%$ on average (Figure 5).

Figure 5: GSEs senior CDS premium and bond price
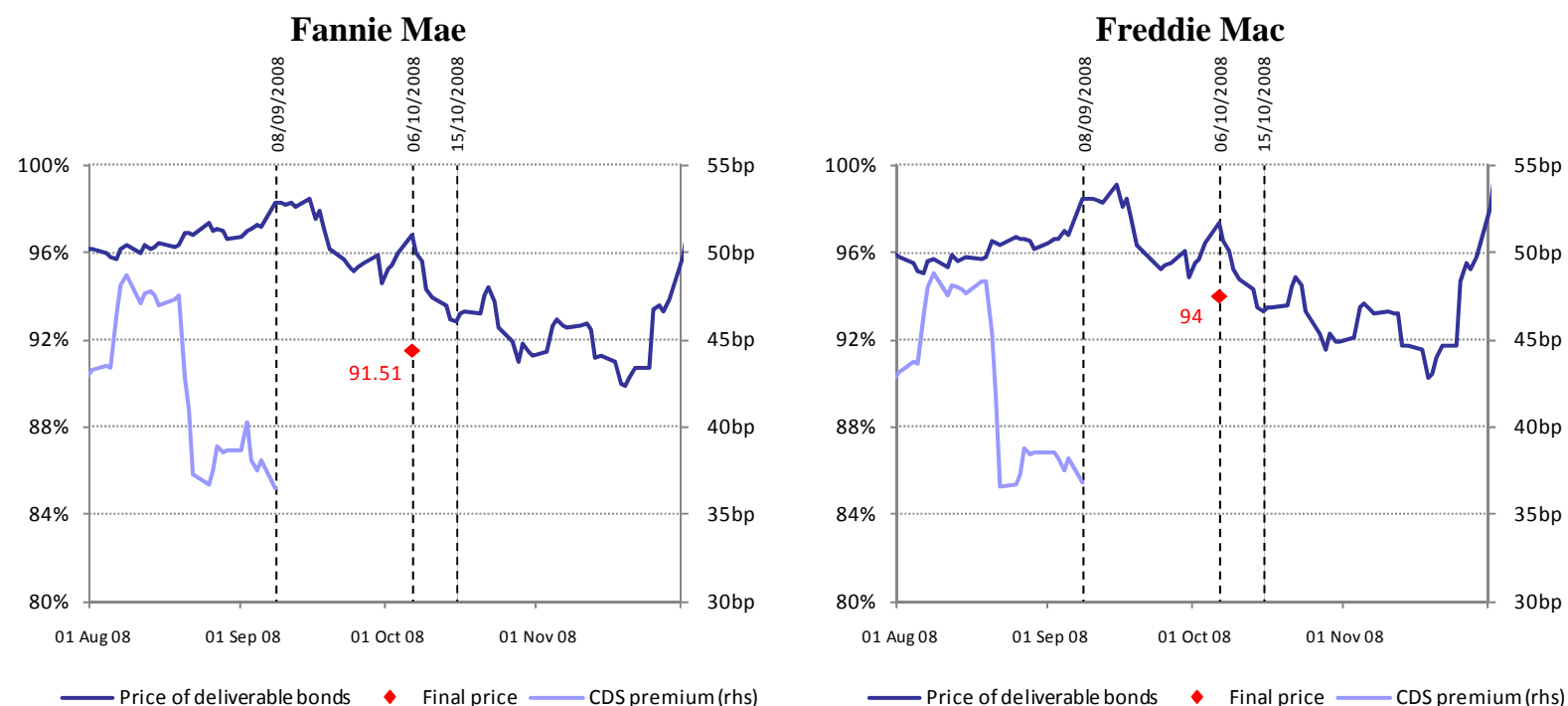

Dates: 08/09/08: default announced; 06/10/08: auction; 15/10/08: settlement. Sources: Bloomberg, Creditex, ISDA, Markit. 
Paradoxically, auctions on the GSEs' subordinated debt led to recovery rates higher than prices for senior bonds. The scarcity of deliverable obligations explains this result. Indeed, the total amount of subordinated bonds deliverable in the auction was very small (USD 8 billion and USD 5 billion for Fannie Mae and Freddie Mac respectively) in comparison with the outstanding credit protection on the two firms, estimated to as much as USD 1.2 trillion, according to Reuters. For the record, the total debt of the two GSEs reached USD 1.6 trillion.

In the first step of the auction, the sum of physical request to sell was equal to zero, leading to a buy net open interest. The final price was driven by this lack of market participants willing to physically deliver subordinated bonds and the net open interest was exhausted at a recovery rate close to par and higher than the final price for senior bonds $(99.9 \%$ and $98 \%$ for Fannie Mae and Freddie Mac, respectively).

\subsection{Lehman Brothers and Washington Mutual: uncertainty about the amounts at stake}

Lehman Brothers was the fourth-largest US investment bank and a major counterparty on the market, having written hundreds of thousands of contracts. This problem was partly resolved over the weekend preceding the failure announcement during a netting session supervised by the Depository Trust \& Clearing Corporation (DTCC) (Moody's, 2008), which enabled more than 300,000 CDS contracts with Lehman Brothers as a counterparty to be taken off the market. Moreover, notional amounts on the Lehman Brothers entity were also very large, ranging between USD 200-500 billion (Yelvington and Taggert, 2008). The most commonly cited figure, reported by the Financial Times, was USD 400 billion. The sheer size of these amounts created doubt that sellers would be able to honour their commitments.

The Financial Times and ISDA estimated the gross notional value of CDS contracts written on Lehman Brothers at USD 400 billion just after the failure. Based on this amount and a recovery rate of 8.625\%, default settlement would have entailed an enormous transfer of USD 366 billion from protection sellers to buyers. These estimated pre-settlement gross amounts greatly overestimate net positions. Moreover, they bear no relation to the figure of USD 72 billion reported by DTCC at that time for all Lehman Brothers contracts recorded in its Trade Information Warehouse (TIW), which covered $90 \%$ of CDS between dealers according to DTCC. There are thus questions over the actual CDS amounts involved (Gerson Lehrman Group, 2008).

The final settlement is known to have totalled USD 5.2 billion. If the recovery rate was $8.625 \%$, we can deduce that the settled contracts corresponded to a notional value of $5.2 /(1-8.625 \%)=$ USD 5.7 billion. As the final settlement took place after market participants' positions were netted, the amounts involved were considerably reduced. Based on the figure of USD 72 billion reported by DTCC, the netting process, which reduced the notional value to USD 5.7 billion, divided the positions by a factor of 12.6, giving a ratio of $7.9 \%$ between net and gross values. This is not substantially different from the 5.7\% netting ratio estimated by the BIS (Gerson Lehrman Group, 2008). If the gross notional value was USD 400 billion, as reported in the press, netting made it possible to reduce the gross positions by much more, i.e. to $1.3 \%$. This is not an unrealistic ratio either, however, given its similarity to Fitch's estimate of $2 \%$. All in all, given the contradictory (but not refuted) information in circulation, the gross amounts involved can still not be identified with certainty.

In the case of Lehman, the relationship between the bond price and CDS premium shows opposing movements around the time of the failure (Figure 6). The CDS premium, which stood at $280 \mathrm{bp}$ in August, leapt to 630 bp just before the failure was announced. In fact, the final trades of 12 September, 
which are not recorded in Bloomberg data, were executed at much higher premiums. Meanwhile, the average price of Lehman bonds plummeted. Trading at $85 \%$ of par until early September, it collapsed just before the failure was announced, falling to approximately $30 \%$ at end-September and $20 \%$ in October. After the failure, it is noteworthy that the CDS settlement price from the auction (8.625\%) was markedly lower than the price of the underlying bonds, which were trading at around $12 \%$ of par the day before the auction. This differential reflects the closing-off of arbitrage opportunities between the underlying and CDS, whose market was frozen by the auction procedure. Uncertainty before the auction about the amounts that would be involved could have contributed to this result.

In the case of Washington Mutual, the auction ended with a recovery rate of $57 \%$, well below that of the secondary market of about 65\% two days before the auction (Figure 8). Washington Mutual was the United States' largest savings and loan association before its failure in September 2008. Huge losses on the subprime market, especially via Option Adjustable Rate Mortgages (ARMs) led the Office of Thrift Supervision (OTS) to place the firm into the receivership of the Federal Deposit Insurance Corporation (FDIC) on 25 September, after a massive bank run of USD 16.4 billion in deposits on a 10-day period. The next day, Washington Mutual filed for chapter 11 of Bankruptcy Code, which was the largest bank failure in the United States up to date, triggering CDS referencing the bank.

Washington Mutual's CDS were very actively traded, and a large number of dealers had actually stacked positions, buying and selling protection on the bank, which were finally offset (Reuters, 2008). The net open interest at the end of the first step of the auction, USD 988 million to sell, was low compared to Lehman Brothers net open interest of USD 4.9 billion. In the second step of the auction, a smaller number of bid orders than in the Lehman case was posted by participants to the auction (195 vs. 435 bids) and a higher number orders was necessary to exhaust the open interest (87 vs. 71 bids), which pushed the final price down.

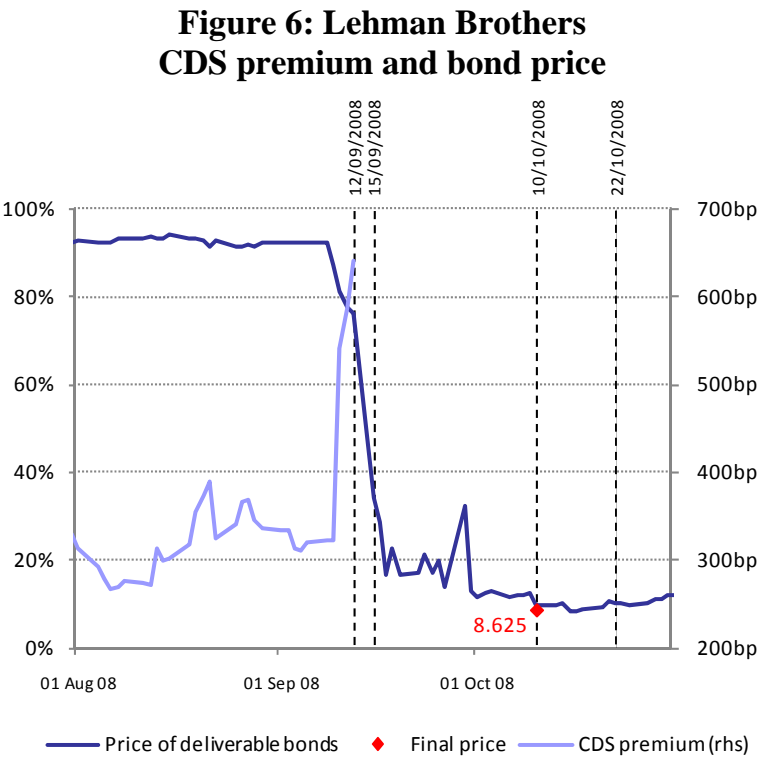

Dates: Friday 12/09/08: last day of trading on CDS market; Monday 15/09/08: default announced; 10/10/08: auction; 22/10/08: settlement.

Sources: Bloomberg, Creditex, ISDA, Markit.
Figure 7: Washington Mutual CDS premium and bond price

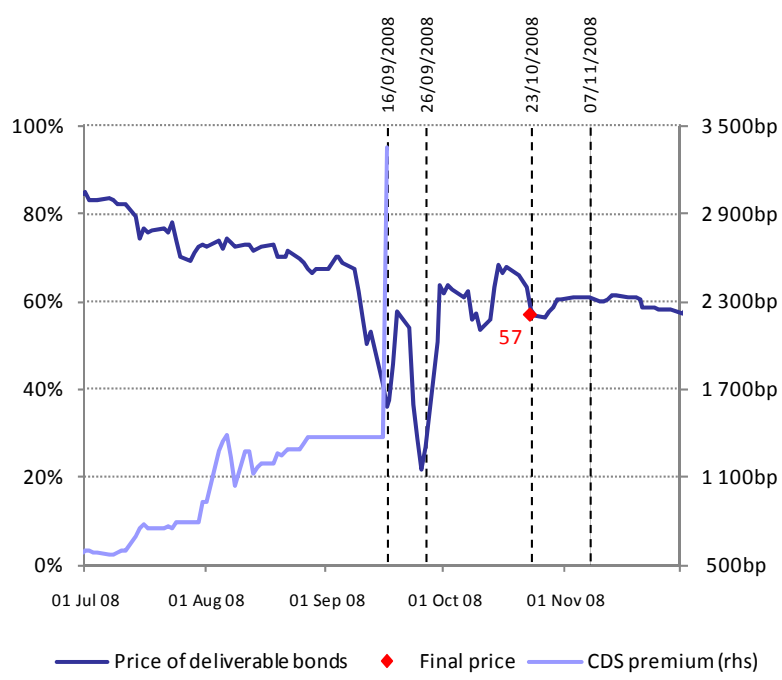

Dates: 16/09/08: last day of trading on CDS market; 26/09/08: default announced; 23/10/08: auction; 07/11/08: settlement. 


\subsection{Thomson: squeeze effects in a restructuring credit event}

CDS contracts and market practices were standardized in 2009, though still diverging on the effects of a restructuring (Duquerroy et al., 2009). On the one side, North American practices on credit events were restated by the ISDA CDS in the so-called "Big Bang" that came into force on April $82009^{14}$. For each major economic area ${ }^{15}$, a Determination Committee was created to decide whether a credit event has occurred and determine the terms of any auction. The Big Bang excludes restructuring from the list of credit event triggering American CDS. Indeed, the law of the United States prompts firms to file under chapter 11 of Bankruptcy Code before restructuring their debt, which triggers automatically a bankruptcy credit event. Consequently, restructuring credit events are very scarce on North American CDS. Additionally, restructuring events are difficult to detect and market participants had considered dropping restructuring on North American CDS for years. At the time the Big Bang took place, 27.1\% of North American CDS were "No Restructuring" trades according to Markit.

On the other side, there is no unified legal framework for European countries and features comparable to chapter 11 do not exist. Consequently, 99.3\% of European CDS include a restructuring clause and excluding restructuring from the list of credit events in European contracts was hence hardly possible ${ }^{16}$. On 27 April 2009, a "Small Bang” concerning Europe, filled out the "Big Bang” in order to extend the auction process to restructuring event ${ }^{17}$.

When a CDS is triggered because of a restructuring event, maturity restrictions apply on deliverable obligations. To take into account these limitations, buckets have been defined in order to aggregate CDS and deliverable bonds according to their maturity. A limitation date is associated to each bucket: 2.5 years, 5 years, 7.5 years, 10 years, 12.5 years, 15 years, 20 years and 30 years. Shorter maturity obligations are always deliverable in longer maturity buckets. If a CDS is positioned in a bucket where no bonds are deliverable, it will be moved in a shorter maturity bucket which includes a deliverable obligation.

Restructuring actually involves a multiple auction mechanism as an auction can occur in each bucket including both CDS and deliverable obligations. The Determination Committee determines whether an auction will take place in a given bucket by applying the " $500 / 5$ " criterion. An auction will automatically be held if 500 or more CDS are triggered in a bucket and 5 or more dealers are counterparties to these contracts. If the criterion is not validated, the Determination Committee conducts a vote to determine if an auction should still take place. To ensure that parties to a CDS have the ability to settle via the auction, a "movement option" can be exerted in the case an auction is not held in a given bucket. This means that if the CDS is triggered by the protection buyer, the trade can be moved to the next earliest maturity bucket; if the CDS is triggered by the protection seller, the trade can be moved to the 30 year maturity bucket if there is an auction for it. This asymmetry aims at maximizing the number of bonds the protection buyer will be able to deliver when he is not the one to have triggered the contract. Lastly, protection buyers can choose not to trigger their CDS, using the "use it or lose it" option, if they anticipate that a subsequent credit event (the bankruptcy of the reference entity) would have a higher pay-out.

\footnotetext{
${ }^{14}$ See Markit (2009a) for a detailed review of the CDS Big Bang.

15 Americas, Asia excluding Japan, Australia - New Zealand, Europe - Middle East - Africa (EMEA), Japan.

${ }^{16}$ Market players assess the cost of the restructuring clause to about 5 bp to $10 \mathrm{bp}$, compared to a "No Restructuring" contract on the same reference entity.

See Markit (2009b) for a detailed review of the CDS Small Bang.
} 
The first restructuring auction under the "Small Bang" concerned the French electronics firm Thomson on 22 October 2009. Because all the debt of the company was privately placed, it took two months to the European Determination Committee to draw up the list of deliverable obligations. According to the DTCC and ISDA, Thomson CDS contracts amounted to about USD 2.1 billion and 7,496 contracts were triggered. An auction took place for 3 buckets: 2.5 years, 5 years and 7.5 years. The auction for the shortest maturity produced a surprisingly high recovery rate of $96.25 \%$, compared to final rates for the 5 year and 7.5 year maturities, of $63.125 \%$ and $63.25 \%$, respectively. The large discrepancies in the final prices across maturities have cast doubts on the efficiency of the auction mechanism in case of a restructuring (Merriman and Baird, 2009).

As a matter of fact, the short list of deliverable obligations led to a scarcity of available securities in the 2.5 year bucket. This shortage was moreover exacerbated by the high demand in Thomson bonds, due to the inclusion of Thomson in several off-the-run iTraxx Europe indexes. The small sell open interest of the 2.5 year bucket, USD 80.967 million, was exhausted by a single order exactly equal to the open interest, posted by J.P. Morgan at a very high bid of $96.25 \%$. Ending with a high recovery allows low payments for cash settlements, which would be rational for J.P. Morgan if we assume that the bank was a net protection seller.

For longer term buckets, i.e. 5 years and 7.5 years, final prices were significantly lower, compared to the 2.5 year bucket. In the first stage of these two auctions, Deutsche Bank provided nearly $75 \%$ of the sell physical requests ${ }^{18}$, leading to larger open interests of USD 221 million and USD 148 million for the 5 year and 7.5 year bucket respectively. Consequently, a larger number of bid orders was needed to exhaust these open interests to sell, shrinking the final price. Assuming that Deutsche Bank was a net protection buyer, the low recovery rate of the longer buckets would ensure higher payments from protection sellers.

\subsection{CIT auction: the possible impact of CDO deals}

Lack of information about the underlying strategies settled by CDS buyers and sellers can also make the final price unpredictable. CIT, a major financial institution in the United States, went bankrupt on November 3 2009. It was a lender for small and medium size firms. CDS on CIT were highly traded. CIT settlement had the largest outstanding volumes the auction process had seen to date: around USD 3.1 billion in single name CDS and USD 2.9 billion in the CDX indexes the firm was included in. Moreover, CIT's CDS were very popular items to include in synthetic CDOs, which are not registered by DTCC. In July 2008, 2,470 CDO tranches with exposure to CIT had been rated by Standard \& Poor's. A significant part of the outstanding amounts of CDS was hence impossible to assess (Brettell, 2009).

Two types of strategies can explain diverging guesses about the final price witnessed before the auction. First, banks that originate the synthetic CDOs hedged their exposures by selling CDS on the underlying reference entities ${ }^{19}$. Consequently, they would have sold large amounts of CDS on CIT and

\footnotetext{
${ }^{18}$ i.e. USD 228 million of the USD 365 million of deliverable obligations for the 5 year bucket and USD 254 million of the USD 286 million of deliverable obligations for the 7.5 year bucket. Deutsche Bank also contributed to USD 120 million of the USD 150 million deliverable bonds in the case of the 2.5 year bucket.

${ }^{19}$ The bank that originates a synthetic CDO transfers risk on an underlying basket of credit to a SPV with CDS. The bank is CDS buyer and the SPV CDS seller. Premia paid by the bank to the SPV are used to remunerate investors in the CDO. In most cases, the bank would hedge its position by selling CDS on the reference entities included in the CDO and would then act as CDS seller in an auction on an underlying reference entity.
} 
would receive bonds at the settlement date; which means they had to buy them in the auction. A large amount of orders to buy would have driven up the price of underlying bonds as well as the final price.

Second, a potentially high number of investors bought CDS on CIT in order to hedge their exposure on underlying bonds or set up CDS basis trades. They were expected to deliver the underlying bond at the settlement date and hence would be sellers of bonds in the auction, pushing down the final price and the price of underlying bonds.

The first type of strategies certainly prevailed as the average price of underlying bonds continuously increased throughout the months preceding the credit event (Figure 8). Between, 30 October and 3 November 2009, date of the credit event, the price increased by 5.5\%. An additional rise in price of $2.9 \%$ occurred on the secondary market between the bankruptcy and the auction.

During the first step of the auction process, requests to sell the bonds (USD 1.5 billion) were almost twice those to buy (USD 785 million). Consequently, market participants posted orders to buy bonds in the second step. Because of its small size, USD 729 million, compared to Lehman Brothers for instance (USD 4.92 billion), the net open interest was quickly exhausted. The final price, $0.6 \%$ higher than the average price of underlying bonds the day of the auction (68.125\%), was driven by these buying pressures.

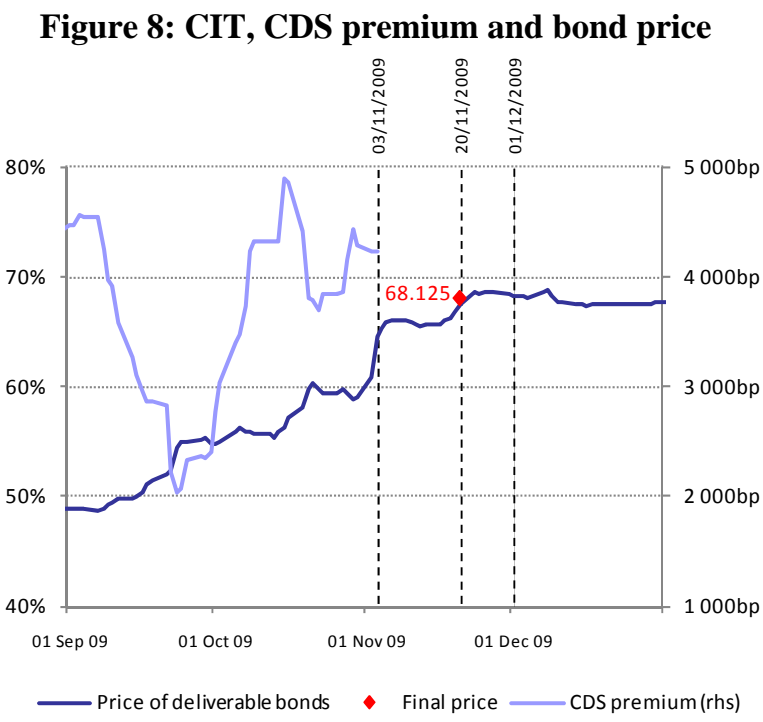

Dates: 03/11/09: default announced; 20/11/09: auction; 01/12/09: settlement. Sources: Bloomberg, Creditex, ISDA, Markit.

\section{RECENT AND ONGOING REFORMS}

Some developments have already contributed to improve the functioning of the CDS market, others are still under way. First, the transfer of CDS from one market participant to another has been facilitated by different steps and resulted in a trade compression. The use of DTCC's electronic platform Deriv/SERV to automate and confirm electronically CDS trades has reduced the volume of outstanding confirmation by $75 \%$ since 2005 , as well as confirmation times. Subsequently, $99 \%$ of 
CDS transactions eligible to electronic trade were effectively confirmed electronically in 2009 and confirmation times dropped from several weeks in 2005 to 1.1 business days on average in 2009 (ISDA, 2010). Electronic trading facilitated the "novation" of CDS contracts. "Novation" means the transfer of the obligations of a CDS counterparty related to a CDS contract to another market participant. If novation is not confirmed, the transaction is delayed and market participants are facing operational and counterparty risk as it is not possible for them to know if the obligations under the contract have been effectively transferred. Under the 2005 ISDA Novation protocol, when a CDS contract is transferred from a given counterparty to another one, electronic confirmation is used to reassign the obligations under the contract before transferring the contract to the new entity.

Consequently, there has been a drastic reduction in redundant contracts due to interlocking positions between financial participants. This trade compression has consisted in eliminating positions that can be multilaterally netted from the portfolios of several dealers, replacing them with a smaller number of contracts with the same net residual exposure. According to TriOptima, leading firm in compression services for CDS contracts through its TriReduce process, 30.2 trillion USD in CDS notional were eliminated in 2008. The contraction in the market size can therefore be attributed to trade compression. This has contributed to mitigate the counterparty risk.

The hardwiring of the auction process has benefited from these innovations. These regular compression cycles have reduced operational risk and facilitated the settlement of credit events. Moreover, since 2008, specific compression processes have been put into place in order to reduce interlocking positions on a defaulted firm before the auction (Freddie Mac and Fannie Mae, Lehman Brothers and Thomson among others).

Second, the Big Bang Protocol on American reference entities has rationalised market practices since 8 April 2009 on; the Small Bang Protocol has done the same for European ones, since 27 July 2009. The auction processes have been automatically implemented when credit events occurred since and are retroactively applied to existing contracts. Moreover, changes in the North American and European Convention for CDS contracts modified the way single-names CDS were quoted. The use of fixed coupon and upfront payments to trade CDS, similarly to CDS indices, rather than the CDS premia, fostered the standardisation of CDS contracts in order to facilitate their clearing in a central counterparty clearing house (CCP) ${ }^{20}$.

Third, the global regulatory response is still pending, although first elements have been already implemented. The public authorities called for all contracts to be recorded in a common repository. At the present time, this means that market participants have to record their contracts in the Trade Information Warehouse set up by DTCC in 2006. This initiative has helped to mitigate operational risk through increased automation and electronic trade confirmation. This infrastructure aims at recordkeeping and maintenance of the data relative to CDS transactions, in order to provide supervisors, as well as market participants, with an accurate view of the underlying obligations and of the risks related to the market and improve market transparency. Moreover, the storage of CDS data in the Trade Information Warehouse ensures the legal enforceability of the contracts (CPSS, 2010).

The move to a centrally cleared market has become a key objective. The recent creation of central counterparty for CDS is designed for transferring counterparty risk to structures that can absorb the shock of a default by a major market participant. CCPs also ensure better collateralisation standards by imposing initial and variation margins on a daily or intraday basis. These margin calls are

\footnotetext{
${ }^{20}$ The Big Bang Protocol, the Small Bang Protocol and the convention changes are described in details in Markit (2009a, 2009b).
} 
complemented by a clearing fund, which is constituted by the individual contributions of the clearing members and allows risk mutualisation in case of default of one of the members (CPSS, 2007). Four CCPs currently clear CDS contracts. The first was launched in March 2009 by the Intercontinental Exchange (ICE Trust) based in Atlanta, for American CDS indices and single-name contracts. Its subsidiary, ICE Europe, clears European single-name CDS and indices. It went live in July 2009. Two European structures, EUREX Credit Clear and LCH. Clearnet SA, launched in July 2009 and March 2010 respectively, also clear European CDS. Mid-2010, about 6.5 trillion USD notional has been cleared by the four CCPs, of which $97 \%$ by ICE Trust and ICE Europe.

Participation to a CCP grants a single framework and reduces legal and operational risks. However, this framework imposes a standardisation of cleared products. On the one hand, it may improve the liquidity of these products, which is a condition for the CCP to ensure efficient hedging and liquidation of its position when a participant defaults. On the other hand, the need for standardisation limits the range of products that a CCP could clear, as a significant number of trades involves CDS with poor liquidity. At the moment, single-name CDS account for only $3 \%$ of the notional cleared by the four CCPs.

\section{CONCLUSION}

When large financial firms such as Lehman Brothers or Washington Mutual failed, there was much concern about the ability of the CDS market to cope with a shock of that magnitude. In the end, these defaults were settled smoothly through the netting of positions and an auction process introduced in 2005. The netting of market participants' gross positions helped to clean up a situation that started out as a huge tangle of crossed positions. By reducing the number of contracts, the netting drastically reduced participants' exposure to counterparty risk and the amount of protection sold on the defaulting firms. The auction process helped to ensure an orderly process by guaranteeing a single price for all holders of protection on the firms. The smooth running of the auction process has prompted its generalisation by market participants to every settlement since then. Nevertheless, the close examination of several cases shows that the auction process is not completely flawless and can yield to biases in the final price. This points to the limits of the auto-regulation of an OTC market.

More importantly, the concerns raised during the crisis have set in motion a train of reforms. Counterparty risk has become a major threat because of the large amounts involved and the low recovery rates. It is now considered to have been needlessly magnified by interlocking positions on the market. The lack of clarity about positions, owing to the market's OTC nature, has shown the need for reliable statistics on positions. Regulatory measures have already been taken to address these issues, some are still under way. The move to a central counterparty clearing is a pivotal tool to mitigate the risks. The recording of all trades by DTCC is also seen as a key element to provide supervisors with the necessary information on the market evolution. 


\section{REFERENCES}

Andritsky, J. R. and M. Singh (2006), "The pricing of credit default swaps during distress", IMF Working Paper 06/254.

Aunon-Nerin, D., D. Cossin, T. Hricko and Z. Huang, (2002), "Exploring for the determinants of credit risk in default swap transaction data: Is fixed-income markets' information sufficient to evaluate credit risk?", Research Paper 65, FAME.

Baba, N. and M. Inada, (2007), "Price discovery of credit spreads for Japanese mega-banks: Subordinated bond and CDS", Discussion Paper 2007-E-6, Institute for Monetary and Economic Studies, Bank of Japan, 2007.

BIS, Bank for International Settlements (2009), "Quarterly Review", December.

Blanco, R., S. Brennan and I. W. Marsh, (2005), "An empirical analysis of the dynamic relationship between investment grade bonds and credit default swaps", Journal of Finance 60, no. 5, p. 22552281.

Brettell, K. (2009), "Strong bank bid could squeeze CIT’s CDS auction", Reuters, 18 November.

Brunnermeier, M. K. (2009), "Deciphering the Liquidity and Credit Crunch 2007-2008", Journal of Economic Perspectives 23, no. 1, p. 77-100.

Cossin, D. and H. Lu (2005), "Are European corporate bonds and default swap markets segmented?", Working Paper 153, FAME, 2005.

Coudert, V. and M. Gex (2010a), "Contagion inside the CDS market: the GM and Ford crisis in 2005", Journal of International Markets, Money, Finance and Institutions n²0, p. 109-1034.

Coudert, V. and M. Gex (2010b), "Credit Default Swaps or Bond Market, Which Leads the Other?”, Bank of France Financial Stability Review n ${ }^{\circ} 14$, July.

CPSS (2007), "New developments in clearing and settlement arrangements for OTC derivatives", Bank for International Settlements, March.

CPSS (2010), "Considerations for trade repositories in OTC derivatives markets", Consultative Report, Bank for International Settlements, May.

Credit Sights, (2008a). "CDS: Guidebook To The Upcoming Auctions", 1 October.

Credit Sights, (2008b). "CDS: Auctions, Exchanges And Coming Changes", 7 October.

Crouch, P. and I. W. Marsh, (2005), "Arbitrage Relationships and Price Discovery in the Autos Sector of the Credit Market", Working Paper, Cass Business School.

De Wit, J (2006), "Exploring the CDS-bond basis", National Bank of Belgium, Working Paper Research 104.

Duffie D. (1999), "Credit swap valuation", Financial Analysts Journal 55, p. 73-87.

Duffie, D. (2010), “Is There a Case for Banning Short Speculation in Sovereign Bond Markets?”, Financial Stability Review, Bank of France, Special Issue on Over the Counter Derivatives, June.

Duquerroy, A., N. Gauthier and M. Gex (2009), "Credit default swaps and financial stability: risks and regulatory issues", Banque de France, Financial Stability Review, no. 13, p. 75-88.

ECB (2009), "Credit Default Swaps and counterparty risk", August. 
Eichengreen, B., A. Mody, M. Nedeljkovic and L. Sarno (2009), "How the subprime crisis went global: evidence from bank credit default swap spreads”, NBER Working Paper 14904, April.

Fitch (2007), "CDx Survey", Special Report, 16 July.

Gerson Lehrman Group (2008), "Lehman CDS Settlement - The Dog that Didn't Bark? " 28 October, http://www.glgroup.com/News/Lehman-CDS-Settlement-\%E2\%80\%93-The-Dog-that-Didnt-Bark$-28832 . h t m l$.

Helwege, J., S. Maurer, A. Sarkar, Y. Wang, (2009) "Credit Default Swaps Auctions", Federal Reserve Bank of New York Staff Report no. 372.

Houweling, P. and T. Vorst, (2005), "Pricing default swaps: Empirical evidence", Journal of International Money and Finance 24, p. 1200-1225.

Hull, J. and A. White (2000), "Valuing credit default swaps I: No counterparty default risk", Journal of Derivatives 8, p. 29-40.

IMF, International Monetary Fund (2008), Global Financial Stability Report, October.

ISDA (2008), "Lehman CDS Protocol", October, http://www.isda.org/2008lehmancdsprot/docs/ Lehman-CDS-Protocol.pdf.

ISDA (2010), "2010 ISDA Operation Benchmarking Survey", http://www.isda.org/c_and_a/pdf/ ISDA-Operations-Survey-2010.pdf.

Jorion, P. and G. Zhang (2007), "Good and bad credit contagion: Evidence from credit default swaps", Journal of Financial Economics 84, no. 3, p. 860-883.

Longstaff, F. A., S Mithal and E. Neis (2005), "Corporate Yield Spreads: Default Risk or Liquidity? New Evidence from the Credit-Default Swap Market", Journal of Finance 60, no. 5, p. 2213-2253.

Markit (2009a), "The CDS Big Bang: Understanding the changes to the global CDS contract and North American conventions", 13 March.

Markit (2009b), "CDS Small Bang: Understanding the global contract and European convention changes", 20 July.

Markit and Creditex, (2010), "Credit event auction primer", February, http://www.markit.com/ information/affiliations/fixings/auctions/docs/credit_event_auction_primer.pdf.

Martin, B. and T. Lasarte (2008), "Bye-bye Basis", Credit Strategy Europe, Merrill Lynch, 5 March.

Matthews, D. and B. Yelvington (2008), "Credit Default Swaps: Will They Change the Course of Bankrupcy?", Credit Sights, 11 juin.

Merriman, J. And J. Baird (2009), "Thomson CDS auction a good deal for some", Reuters, 22 October.

Norden, L. and M. Weber, (2004), "The comovement of credit default swap, bond and stock markets: An empirical analysis", CEPR Discussion Paper no. 4674.

O’Kane, D. and R. McAddie, (2001), "Explaining the Basis: Cash versus Default Swaps", Lehman Brothers Fixed Income Research, May

Olléon-Assouan, E, (2004). "Techniques used on the credit derivatives market: credit default swaps", Financial Stability Review 4, Banque de France. 
Pengelly, M. (2008), "Fannie and Freddie auctions raise questions about CDSs", Risk Magazine, 7 October.

Purtle, L. and B. Yelvington (2008), "CDS: A Market with More Questions than Answers", Credit Sights, 23 September.

Reuters (2008), "WaMu CDS sellers face 43 pct insurance payouts", 23 October.

Segoviano, M. and M. Singh (2008), "Counterparty Risk in the Over-The-Counter Derivatives Market", IMF Working Paper 08/258.

Singh, M. and J. Aitken (2009), "Counterparty Risk, Impact on Collateral Flows and Role for Central Counterparties", IMF Working Paper 09/173.

Singh, M. and C. Spackman (2009), "The Use (and Abuse) of CDS Spreads During Distress", IMF Working Paper, 09/62.

Weistroffer, C. (2009), "Credit Default Swaps, heading towards a more stable system", Deutsche Bank Research, Current issues, 21 december.

Yelvington, B. and C. Taggert (2008), "CDS Auction Madness", Credit Sights, 10 October.

Zhu, H. (2006), "An empirical comparison of credit spreads between the bond market and the credit default swap market", Journal of Financial Services Research, vol 29 no. 3, June, p. 211-235. 


\section{LIST OF WORKING PAPERS RELEASED BY CEPII}

An Exhaustive list is available on the website: \|www.cepii.fr. To receive an alert, please contact Sylvie Hurion (sylvie.hurion@cepii.fr).

No

2010-16 The Impact of the 2007-10 Crisis on the Geography of Finance

2010-15 Socially Responsible Investing: it takes more than Words

2010-14 A Case for Intermediate Exchange-Rate Regimes

2010-13 Gold and Financial Assets: Are they any Safe Havens in Bear Markets?

2010-12 European Export Performance

2010-11 The Effects of the Subprime Crisis on the Latin American Financial Markets: An Empirical Assessment

2010-10 Foreign Bank Presence and its Effect on Firm Entry and Exit in Transition Economies

2010-09 The Distorted Effect of Financial Development on International Trade Flows

2010-08 Exchange Rate Flexibility across Financial Crises

2010-07 Crises and the Collapse of World Trade: the Shift to Lower Quality

2010-06 The heterogeneous effect of international outsourcing on firm productivity

2010-05 Fiscal Expectations on the Stability and Growth Pact: Evidence from Survey Data

2010-04 Terrorism Networks and Trade: Does the Neighbor Hurt

\section{Authors}

G. Capelle-Blancard Y.Tadjeddine

G. Capelle-Blancard

S. Monjon

V. Salins \& A. BénassyQuéré

V. Coudert \& H. Raymond

A. Cheptea, L. Fontagné \& S. Zignago

G. Dufrénot, V. Mignon \& A. Péguin-Feissolle

O. Havrylchyk

A . Berthou

V. Coudert,

C. Couharde \& V. Mignon

A. Berthou \& C. Emlinger

F. McCann

M. Poplawski-Ribeiro \& J.C. Rüle

J. de Sousa, D. Mirza \& T. Verdier 
No

Tittle

2010-03 Wage Bargaining and the Boundaries of the Multinational Firm

2010-02 Estimation of Consistent Multi-Country FEERs

2010-01 The Elusive Impact of Investing Abroad for Japanese Parent Firms: Can Disaggregation According to FDI Motives Help

2009-39 The Effects at Home of Initiating Production Abroad: Evidence from Matched French Firms

2009-38 On Equilibrium Exchange Rates: Is Emerging Asia Different?

2009-37 Assessing Barriers to Trade in the Distribution and Telecom Sectors in Emerging Countries

2009-36 Les impacts économiques du changement climatique : enjeux de modélisation

2009-35 Trade, Foreign Inputs and Firms' Decisions: Theory and Evidence

2009-34 Export Sophistication and Economic Performance: Evidence from Chinese Provinces

2009-33 Assessing the Sustainability of Credit Growth: The Case of Central and Eastern European Countries

2009-32 How do different exporters react to exchange rate changes? Theory, empirics and aggregate implications

2009-31 Spillovers from Multinationals to Heterogeneous Domestic Firms: Evidence from Hungary

2009-30 Ethnic Networks, Information, and International Trade: Revisiting the Evidence

2009-29 Financial Constraints in China: Firm-level Evidence

2009-28 The Crisis: Policy Lessons and Policy Challenges

2009-27 Commerce et flux financiers internationaux : MIRAGE-D

2009-26 Oil Prices, Geography and Endogenous Regionalism: Too Much Ado about (Almost) Nothing

2009-25 EU15 Trade with Emerging Economies and Rentier States: Leveraging Geography

2009-24 Market Potential and Development

\section{Authors}

M. Bas \& J. Carluccio

B. Carton \& K. Hervé

L. Hering, T. Inui

\& S. Poncet

A. Hijzen, S. Jean \& T. Mayer

A. López-Villavicencio \& V. Mignon

L. Fontagné

\& C. Mitaritonna

P. Besson \& N. Kousnetzoff

M. Bas

J. Jarreau \& S. Poncet

V. Coudert \& C. Pouvelle

N. Berman, P. Martin \& Thierry Mayer

G. Békés, J. Kleinert \& F. Toubal

G. J. Felbermayr, B. Jung \& F. Toubal

S. Poncet, W. Steingress \& H. Vandenbussche

A. Bénassy-Quéré, B. Coeuré, P. Jacquet \&J. Pisani-Ferry

A. Lemelin

D. Mirza \& H. Zitouna

G. Gaulier, F. Lemoine \& D. Ünal

T. Mayer 
No

Tittle

2009-23 Immigration, Income and Productivity of Host Countries: A Channel Accounting Approach

2009-22 A Picture of Tariff Protection Across the World in 2004 MAcMap-HS6, Version 2

2009-21 Spatial Price Discrimination in International Markets

2009-20 Is Russia Sick with the Dutch Disease

2009-19 Économies d'agglomération à l'exportation et difficulté d'accès aux marchés

2009-18 Local Export Spillovers in France

2009-17 Currency Misalignments and Growth: A New Look using Nonlinear Panel Data Methods,

2009-16 Trade Impact of European Measures on GMOs Condemned by the WTO Panel

2009-15 Economic Crisis and Global Supply Chains

2009-14 Quality Sorting and Trade: Firm-level Evidence for French Wine

2009-13 New Evidence on the Effectiveness of Europe's Fiscal Restrictions

2009-12 Remittances, Capital Flows and Financial Development during the Mass Migration Period, 1870-1913

2009-11 Evolution of EU and its Member States'Competitiveness in International Trade

2009-10 Exchange-Rate Misalignments in Duopoly: The Case of Airbus and Boeing

2009-09 Market Positioning of Varieties in World Trade: Is Latin America Losing out on Asia?

2009-08 The Dollar in the Turmoil

2009-07 Term of Trade Shocks in a Monetary Union: An Application to West-Africa

\section{Authors}

A. Mariya \& A. Tritah

H. Boumellassa, D. Laborde Debucquet \& C. Mitaritonna

J. Martin

V. Dobrynskaya \& E. Turkisch

P. Koenig, F. Mayneris \& S. Poncet

P. Koenig, F. Mayneris \& S. Poncet

S. Béreau,

A. López Villavicencio \& V. Mignon

A. C. Disdier \& L. Fontagné

A. Bénassy-Quéré, Y. Decreux, L. Fontagné \& D. Khoudour-Casteras

M. Crozet, K. Head \& T. Mayer

M. Poplawski Ribeiro

R. Esteves

\& D. Khoudour-Castéras

L. Curran \& S. Zignago

A. Bénassy-Quéré, L. Fontagné \& H. Raff

N. Mulder, R. Paillacar \& S. Zignago

A Bénassy-Quéré, S. Béreau \& V. Mignon

L. Batté, A. Bénassy-Quéré, B. Carton \& G. Dufrénot 
No

2009-06

Macroeconomic Consequences of Global Endogenous

Migration: A General Equilibrium Analysis

2009-05 Équivalence entre taxation et permis d'émission échangeables

2009-04 The Trade-Growth Nexus in the Developing Countries: a Quantile Regression Approach

2009-03 Price Convergence in the European Union: within Firms or Composition of Firms?

2009-02 Productivité du travail : les divergences entre pays développés sont-elles durables?

2009-01 From Various Degrees of Trade to Various Degrees of Financial Integration: What Do Interest Rates Have to Say

\section{Authors}

V. Borgy, X. Chojnicki, G. Le Garrec \& C. Schwellnus

$$
\text { P. Villa }
$$

G. Dufrénot, V. Mignon \& C. Tsangarides

I. Méjean \& C. Schwellnus

C. Bosquet \& M. Fouquin

A. Bachellerie, J. Héricourt \& V. Mignon 
Organisme public d'étude et de recherche en économie internationale, le CEPII est placé auprès du Centre d'Analyse Stratégique. Son programme de travail est fixé par un conseil composé de responsables de l'administration et de personnalités issues des entreprises, des organisations syndicales et de l’Université.

Les documents de travail du CEPII mettent à disposition du public professionnel des travaux effectués au CEPII, dans leur phase d'élaboration et de discussion avant publication définitive. Les documents de travail sont publiés sous la responsabilité de la direction du CEPII et n'engagent ni le conseil du Centre, ni le Centre d'Analyse Stratégique. Les opinions qui y sont exprimées sont celles des auteurs.

Les documents de travail du CEPII sont disponibles sur le site : http//www.cepii.fr.

CEPII

9, RUe Georges Pitard, 75740 Paris Cedex 15

SYLVIE HURION - PUbliCATIONS

TÉL : 0153685514 - FAX : 0153685504

sylvie.hurion@cepii.fr

ISSN : 1293-2574 